ISSN (print): 1698-6180. ISSN (online): 1886-7995

www.ucm.es/info/estratig/journal.htm

Journal of Iberian Geology 38 (1) 2012: 127-144

http://dx.doi.org/10.5209/rev_JIGE.2012.v38.n1.39209

\title{
Active extensional faults in the central-eastern Iberian Chain, Spain
}

\author{
Fallas activas extensionales en la Cordillera Ibérica centro-oriental
}

\author{
J.L. Simón*, L.E. Arlegui, P. Lafuente, C.L. Liesa \\ Dpt. Ciencias de la Tierra, Facultad de Ciencias, Universidad de Zaragoza, \\ c/ Pedro Cerbuna 12, E-50009 Zaragoza, Spain \\ jsimon@unizar.es,arlegui@unizar.es,palomalt@unizar.es,carluis@unizar.es
}

*Corresponding author

Received: 27/06/2011 / Accepted: 29/02/2012

\begin{abstract}
Among the conspicuous extensional structures that accommodate the onshore deformation of the Valencia Trough at the centraleastern Iberian Chain, a number of large faults show evidence of activity during Pleistocene times. At the eastern boundary of the Jiloca graben, the Concud fault has moved since mid Pliocene times at an average rate of 0.07-0.08 mm/y, while rates from 0.08 to $0.33 \mathrm{~mm} / \mathrm{y}$ have been calculated using distinct stratigraphic markers of Middle to Late Pleistocene age. A total of nine paleoseisms associated to this fault have been identified between 74.5 and $15 \mathrm{ka} \mathrm{BP}$, with interseismic periods ranging from 4 to $11 \mathrm{ka}$, estimated coseismic displacements from 0.6 to $2.7 \mathrm{~m}$, and potential magnitudes close to 6.8. The other master faults of the Jiloca graben (Calamocha and Sierra Palomera faults) have also evidence of Pliocene to Late Pleistocene displacement, with average slip rates of 0.06 and $0.11-0.15 \mathrm{~mm} / \mathrm{y}$, respectively. At the eastern boundary of the Teruel graben, the Sierra del Pobo fault has been active since Late Miocene times, at slip rates of 0.06-0.11 mm/y. Quaternary activity its better constrained for the Teruel fault, which offsets two fluvial terraces, with an estimated slip rate of $0.12 \mathrm{~mm} / \mathrm{y}$ since $76 \mathrm{ka}$ BP. A widespread, NNE-SSW trending fault system extends over the easternmost Iberian Chain (Maestrat sector), with abundant proofs of activity during Early to Middle Pleistocene s.1. times. Nevertheless, such proofs are mainly geomorphologic, while dated stratigraphic markers allowing precise assessment of slip rates are absent.
\end{abstract}

Keywords: neotectonics, paleoseismology, normal fault, Jiloca graben, Teruel graben, Maestrat grabens.

Resumen

Algunas de las estructuras extensionales que acomodan tierra adentro la deformación del surco de Valencia en la Cordillera Ibérica centro-oriental son fallas de considerable tamaño que muestran evidencias de actividad durante el Pleistoceno. En el borde oriental 
de la fosa del Jiloca, el desplazamiento de la falla de Concud, desde el Plioceno medio, se ha producido con una tasa media de 0,07-0,08 $\mathrm{mm} / \mathrm{a}$, en tanto que empleando diferentes marcadores estratigráficos de edad Plioceno medio a superior se obtienen tasas que varían de 0,08 a $0,33 \mathrm{~mm} / \mathrm{a}$. Se han identificado un total de nueve paleosismos asociados a esta falla entre 74,5 y $15 \mathrm{ka} \mathrm{BP}$, con periodos intersísmicos que van de 4 a $11 \mathrm{ka}$, desplazamientos cosísmicos estimados desde 0,6 a 2,7 m y magnitudes potenciales cercanas a 6,8. El resto de fallas principales de la fosa del Jiloca (falla de Calamocha y falla de Sierra Palomera) presentan también evidencias de actividad durante el Plioceno al Pleistoceno superior, con tasas de desplazamiento promedio de 0,06 y 0,11-0,15 $\mathrm{mm} / \mathrm{a}$, respectivamente. En el borde oriental de la fosa de Teruel, la falla de Sierra del Pobo ha estado activa desde el Mioceno Superior, con una tasa de desplazamiento estimada de 0,06-0,11 mm/a. Está mejor determinada la actividad cuaternaria de la falla de Teruel, que desplaza dos terrazas fluviales con una tasa estimada en $0,12 \mathrm{~mm} / \mathrm{a}$ desde $76 \mathrm{ka}$ BP. En el Maestrat aparece un sistema de fallas NNE-SSO con abundantes pruebas de actividad durante el Pleistoceno inferior y medio. Sin embargo, estas evidencias son principalmente geomorfológicas y no se cuenta con marcadores estratigráficos datados que permitan estimar con precisión las tasas de desplazamiento.

Palabras clave: neotectónica, paleosismología, falla normal, fosa del Jiloca, fosa de Teruel, fosas del Maestrat.

\section{Introduction}

The Iberian Chain is an intraplate range that shows moderate instrumental and historic seismicity, although contains a significant number of documented active faults. Those showing the most conclusive evidences of recent, continuous activity are linked to the intra-mountain Teruel and Jiloca grabens. Nevertheless, paleoseismological studies are very scarce on them (Simón et al., 2005; Lafuente et al., 2007, 2008a,b, 2010a,b; Gutiérrez et al. 2008, 2009).

This paper presents a synthesis of geological and paleoseismological information about the better documented active faults in the central-eastern Iberian Chain, including those bounding the Jiloca graben (Concud, Sierra Palomera and Calamocha faults), two large and well representative structures of the Teruel graben (Sierra del Pobo and Teruel faults), and a number of faults belonging to the Maestrat graben system, the easternmost extensional onshore ensemble (Fig. 1). Our degree of knowledge about these active faults is not homogeneous. At present, the Concud fault has the most continuous geological and paleoseismological record of activity, so the longest section is devoted to it.

\section{Geological setting}

The central-eastern Iberian Chain shows a large network of Neogene-Quaternary extensional basins (Fig. 1) that postdate the Alpine compressive structures and represent the onshore deformation of the Valencia Trough (Vegas et al. 1979; Roca and Guimerà 1992). They evolved through two successive rift episodes (Simón 1982, 1983): the first one (Miocene) produced the main NNE-SSW trending grabens (Teruel and Maestrat); the second one (Late Pliocene-Quaternary) gave rise to the NNW-SSE trending Jiloca graben and reactivated the Teruel and Maestrat grabens.
The Teruel basin is a half graben with an active eastern boundary made of large N-S striking faults (Fig. 2). These faults produce prominent mountain fronts that separate the graben bottom (usually at 800-1000 m.a.s.1.) from the E1 Pobo and Javalambre massifs (at about 1700 and $2000 \mathrm{~m}$, respectively). The basin is filled with Neogene sedimentary units made of red clastic alluvial deposits that grade laterally into lacustrine carbonates and gypsum. Their ages, well constrained from numerous mammal fossil localities (Godoy et al., 1983a,b; Alcalá et al., 2000), range from the Vallesian (early Late Miocene) to the Villafranchian (Late Pliocene).

The Jiloca asymmetric graben shows an overall NNWSSE trend that results from en-echelon, right releasing arrangement of NW-SE striking normal faults, the largest ones being also located at the eastern boundary: Calamocha, Sierra Palomera and Concud faults (Fig. 2). The visible infill of the Jiloca graben is constituted by an Upper Pliocene to Pleistocene sedimentary sequence made up by alluvial fan, pediment and episodic palustrine deposits, which is underlain at the central sector by marls of probable Neogene age (only observed in boreholes; Rubio and Simón, 2007).

The Maestrat graben system includes the easternmost onshore structures produced by rifting of the Valencia Trough (Fig. 1). Extensional basins initiated during the Late Oligocene to Early Miocene, accommodating a 100 to $250 \mathrm{~m}$-thick sequence of alluvial conglomerates and lacustrine limestones and marls (Anadón and Moissenet, 1996). These basins underwent successive faulting episodes during Late Miocene, Pliocene and Pleistocene times (Simón, 1982; Simón et al., 1983), receiving new alluvial deposits (mainly gravel and silt) that usually do not exceed more than a few tens of meters in thickness.

Mountains surrounding the Teruel and Jiloca basins show extensive erosion surfaces modelling Mesozoic rocks, which locally correlate with the top of the Neogene infill. According to the classic geomorphological 


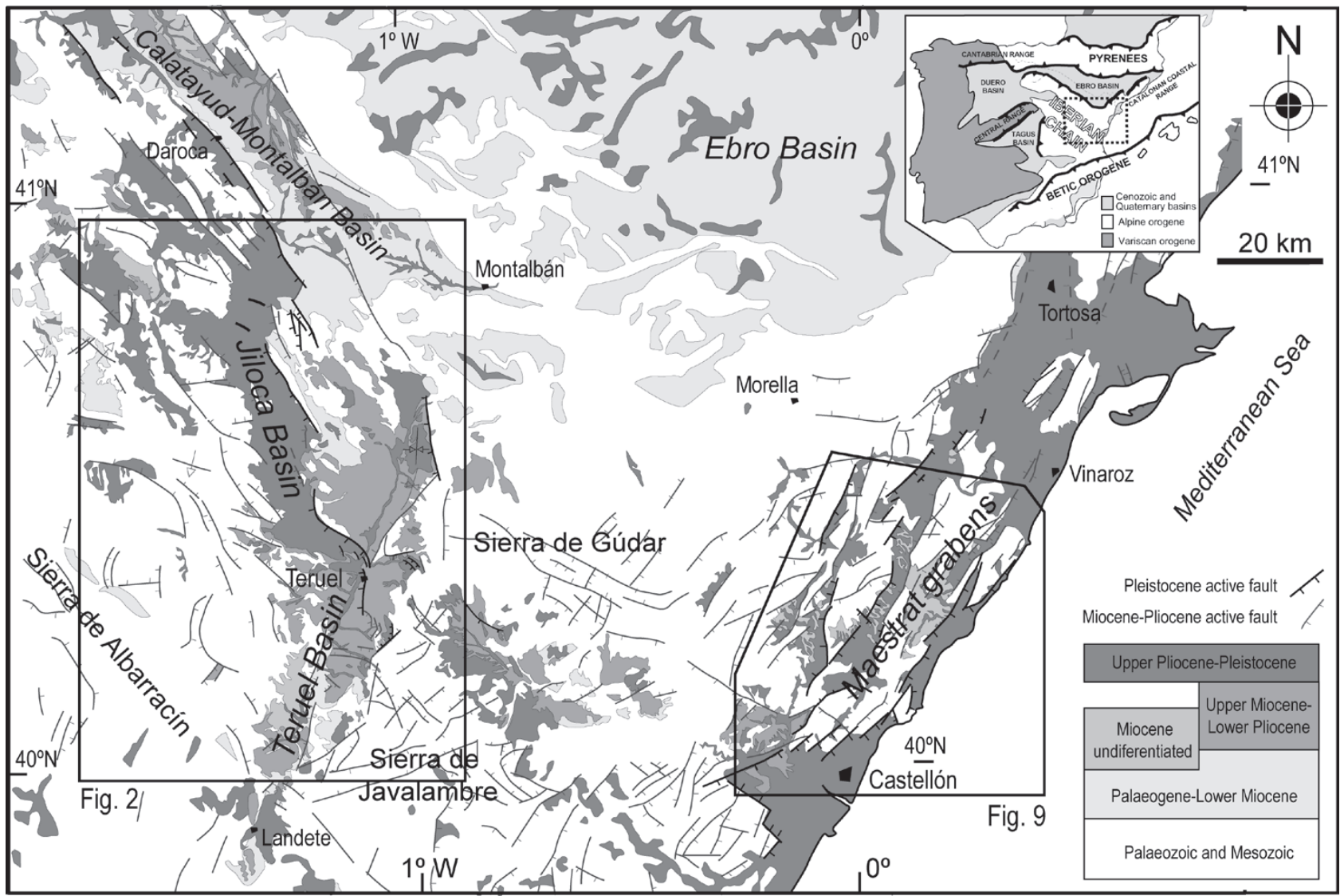

Fig. 1.- Geological map of the central-eastern Iberian Chain showing structures acting since Miocene times. Insert shows location within the Iberian Peninsula.

Fig. 1.- Mapa geológico de la Cordillera Ibérica centro-oriental mostrando las estructuras que han actuado desde tiempos miocenos. La figura insertada muestra la localización dentro de la Península Ibérica.

models for the central Iberian Chain, they were attributed to either a single extensive erosion surface (Fundamental Erosion Surface of the Iberian Chain, FES, Peña et al., 1984) or two distinct nested surfaces (S2 and S3, the latter being restricted to the border of the depression, Gracia et al., 1988, Gutiérrez and Gracia, 1997). These surfaces range from Late Miocene to mid Pliocene in age. Both are younger than a tardi-orogenic planation surface, the Intra-Miocene Erosion Surface (Gutiérrez and Peña, 1976; Peña et al., 1984; S1 of Gutiérrez and Gracia, 1997), which makes the summit of some residual mountains at Sierra de Albarracín, as well as the basal unconformity of the Upper Miocene infill of the Teruel basin. Based on the ages of the oldest mammal sites in the Alfambra-Teruel basin, as well as on magnetostratigraphical constraints, the beginning of the sedimentary infill of this sector (and so the Intra-Miocene Erosion Surface) could be dated close to the Aragonian-Vallesian limit ( $\approx 11.1 \mathrm{Ma}$; Alcalá et al., 2000). The FES has been frequently used as a regional marker for characterizing the geometry of macro-scale recent deformations (Simón, 1982, 1989; Peña et al., 1984; Gracia et al., 1988;
Lozano, 1988). Other authors propose alternative interpretations, such as multiple stepped pediplains developed during Paleogene to early Miocene times within the framework of compressive uplift (González et al., 1998; Guimerà y González, 1998; Casas and Cortés, 2002), or Pliocene to Quaternary karstic corrosion surfaces (Gracia et al., 2003). In this respect, we share the arguments by Rubio and Simón (2007), Rubio et al. (2007) and Simón et al. (2010) in favour of the 'classic' model. Nevertheless, we admit that it should probably be modified in certain massifs, as Gúdar or Sierra del Pobo, where the age of the summit planation surfaces (hence the amplitude of Plio-Pleistocene vertical displacements) has not been proved (see further discussion in Simón, 2007).

The regional stress field linked to recent tectonics of the central-eastern Iberian Chain is relatively well known. It is a biaxial, near 'multidirectional' tension ( $\sigma_{1}$ vertical, $\sigma_{2}$ $\approx \sigma_{3}$ ) with $\sigma_{3}$ trending nearly ENE (Simón, 1989; Arlegui et al., 2005). The trend of the Jiloca graben is essentially controlled by this dominant ENE-WSW extension direction (Simón, 1989). The focal mechanisms available for seisms located within the region, although not quite nu- 
merous, also are consistent with such stress field (Herraiz et al., 2000; analyzed period: 1986 to 1995). The $\sigma_{3}$ trajectories of this biaxial tension field underwent frequent deflections, veering to become either parallel or perpendicular to NNW and NNE major faults, with a tendency for $\sigma_{2}$ and $\sigma_{3}$ axes to switch (Simón 1989; Arlegui et al. 2005, 2006).

Historic and instrumental seismicity of the central-eastern Iberian Chain is low to moderate. In the Teruel region, the epicentres are concentrated at the Jiloca graben margins, the central-southern sector of the Teruel basin, and in the Albarracín and Javalambre massifs (Fig. 3). Apart from the Albarracín massif, epicentres can be reasonably associated to Neogene-Quaternary known faults. Measured magnitudes $(\mathrm{Mb})$ usually range from 1.5 to 3.5 , with maximum $\mathrm{Mb}=4.4$ in the Teruel graben and $\mathrm{Mb}=3.8$ in the Albarracín massif (data from Instituto Geográfico Nacional, IGN). Before the instrumental period, intensities up to VIII were recorded in the Teruel basin (year 1656), VI-VII in the Albarracín massif (1848), and IV-V in the Jiloca graben (1828). Focal depths are always less than $25 \mathrm{~km}$, and typically range from 5 to 15 $\mathrm{km}$, which corresponds to the brittle layer above the basal detachment level, 10-15 km deep, identified by Roca and Guimerà (1992). Most of the available focal mechanisms correspond to normal faults striking around N-S (those numbered as 1, 2, 3, 6 in Fig. 3), while another one (5, south of Teruel) indicates the activation of an E-W striking normal fault that suggests local switching of $\sigma_{2}$ and $\sigma_{3}$ axes. All them are consistent with the features of the regional recent stress field as described above. In the Maestrat region seismicity is even lower, with only two historic earthquakes of intensity $=\mathrm{IV}$ and a number of minor ones $(3.0 \geq \mathrm{M} \geq 2.1)$ recorded since 1990 .

\section{The Jiloca graben: Concud fault}

\subsection{Structure, stratigraphy and morphotectonics: an overview}

The NW-SE striking Concud fault is the southernmost fault bounding the Jiloca graben, and follows the nearly vertical limb of a NW-SE trending anticline (Fig. 2). Such macrostructural relationship, together with a hectometrescale klippe observed in the footwall, and reverse ductile shear bands deforming Lower Triassic clays within the fault zone, suggest that the recent extensional Concud fault represents the negative inversion of a previous reverse, fold-related fault (Lafuente et al., 2010a).

The Concud fault trace is $14.2 \mathrm{~km}$ long, and shows an overall NW-SE strike, which veers towards N-S near its southern tip (Fig. 4). At the central sector, two distinct, nearly parallel traces can be distinguished. The fault is expressed in the landscape as a fault-generated, 60 to $120 \mathrm{~m}$ high mountain front, with conspicuous triangular facets on Jurassic rocks of the central sector, and short, generally non-incised alluvial fans making the piedmont. Detailed field survey and mapping suggest that the fault is not segmented (Lafuente et al., 2010a). Measured dips typically range from 65 to $70^{\circ} \mathrm{SW}$, and the observed striations indicate a nearly pure normal movement. The fault usually put into contact Pleistocene alluvial deposits of the hanging wall with Triassic and Jurassic units of the footwall at the western and central sectors, and with the Neogene units of the Teruel basin at the southeastern one.

The extensional activity of the Concud fault, as far as it has been geologically documented, begun by the latest Ruscinian (mid Pliocene), cutting the previous Upper Miocene-Lower Pliocene infill of the Teruel basin (Fig. 2). Since the latest Ruscinian, the sedimentation was interrupted on its footwall, whereas a complete syntectonic sequence belonging to the Upper Pliocene and Pleistocene were deposited on the hanging wall (Simón, 1983; Moissenet, 1982). The Upper Pliocene sequence includes red alluvial fine-grained sediments with interbedded lacustrine-palustrine carbonates, capped by a pediment cover (Villafranchian pediment). The Pleistocene deposits include fluvial terraces of the Guadalaviar and Alfambra rivers, and short alluvial fans developed from the fault scarp (Peña et al., 1984).

Three main terrace levels have been defined for the Alfambra-Guadalaviar fluvial system (Peña, 1981; Godoy et al., 1983a), although two of them locally split into sublevels (Sánchez Fabre, 1989; Moissenet, 1993). The Upper Terrace is of unknown age. The Middle Terrace has yielded absolute ages (U/Th, TL, and OSL) from 250 $+32 /-25 \mathrm{ka}$ to $116 \pm 4 \mathrm{ka}$ for the main level (Arlegui et al. 2006; Gutiérrez et al., 2008), and $91 \pm 5$ ka for a split, lower level (Lafuente et al., 2008b). The Lower Terrace also shows two sub-levels, the most conspicuous one being dated by OSL from $15.0 \pm 0.9 \mathrm{ka}$ to $14.9 \pm 1.0 \mathrm{ka}$ (Gutiérrez et al. 2008; Lafuente et al., 2008b). We do not refer to other proposals of fluvial terrace sequences, as that cited by Gutiérrez et al. (2011), since they have not been published, neither contrasted up to present.

\subsection{Slip rates}

The average slip rate for the overall extensional history can be calculated from the position and age of the uppermost pretectonic level, i.e. the top of the Early Pliocene lacustrine deposits at the footwall (informal Páramo 2 unit; Godoy et al., 1983a,b; Fig. 4). This unit makes a structural platform at 1180-1200 m.a.s.l. (Celadas pla- 
Fig. 2.- Geological map of the Jiloca and Teruel grabens (see location in Fig. 1). Thicker lines represent active extensional faults. Numbers: relevant sites where slip rates have been calculated from well-known markers.

Fig. 2.- Mapa geológico de las fosas del Jiloca y de Teruel (ver localización en Fig. 1). Las líneas gruesas representan fallas extensionales activas. Números: lugares relevantes donde se han calculado tasas de desplazamiento a partir de marcadores bien conocidos.

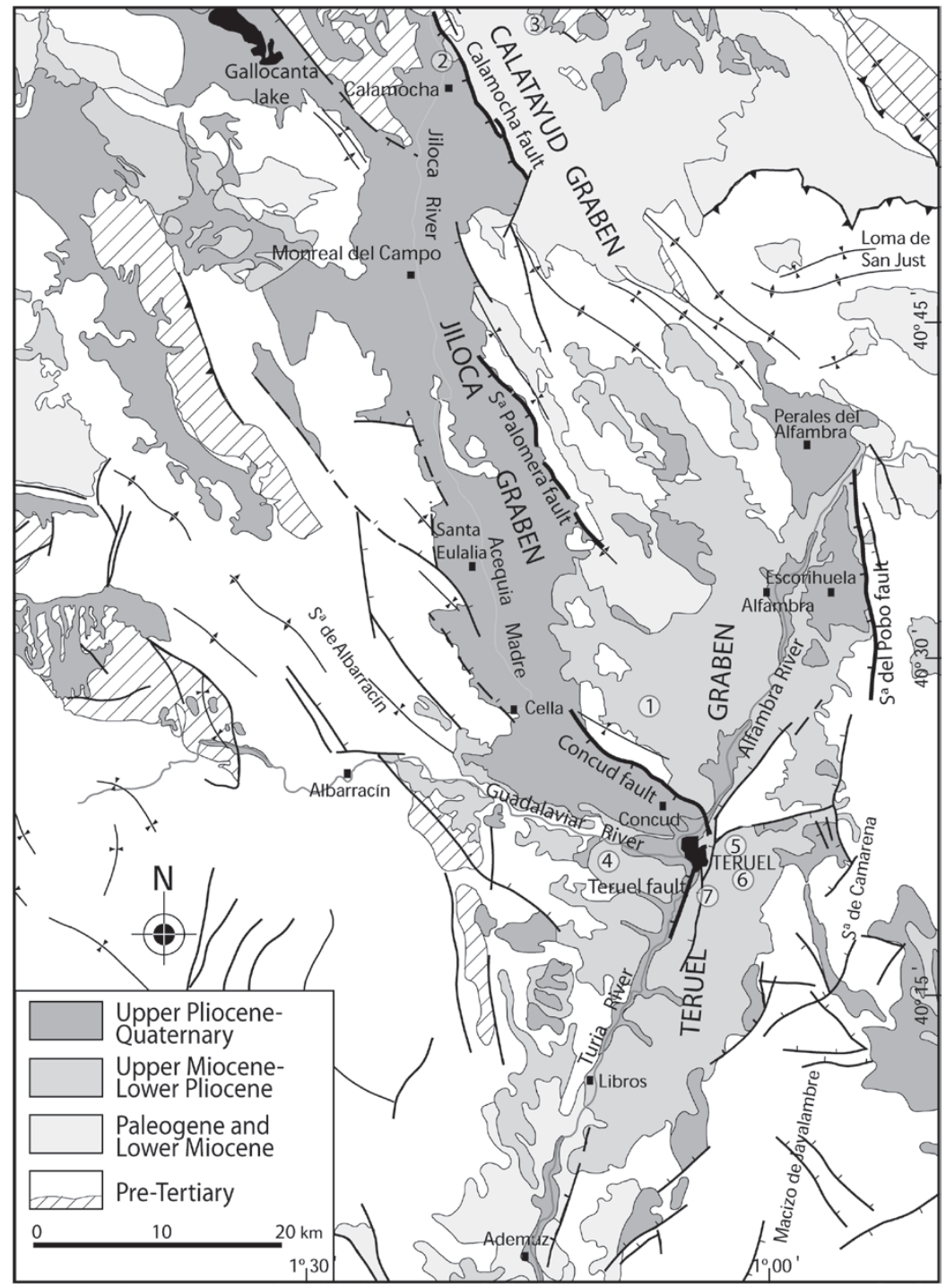

teau; site 1 in Fig. 2), and is dated by mammal fauna in the MN 15b zone (latest Ruscinian; 3.6 Ma; Godoy et al., 1983a,b; Opdyke et al., 1997; Alcalá et al., 2000). At the hanging wall, it appears at 920-940 m.a.s.l., being unconformably covered by Upper Pliocene and Pleistocene red clastic sediments. This involves a minimum post-Early Pliocene vertical offset of about $240 \mathrm{~m}$. Considering an average dip of $70^{\circ}$ and a pure normal movement, this results in a net displacement of $255 \mathrm{~m}$, which could increase up to 290-300 $\mathrm{m}$ if we take into account the probable roll-over geometry at depth. The resulting slip rate is $0.07-0.08 \mathrm{~mm} / \mathrm{y}$ (Simón et al., 2005; Lafuente et al., 2010a; Lafuente, 2011).

Slip rates since Middle Pleistocene times have been inferred at Los Baños (see location in Fig. 4). At this site, the Middle Terrace of the Alfambra river, capped by a tufa level dated between $169 \pm 10$ and $116 \pm 4 \mathrm{ka}$, shows a minimum throw of $36 \mathrm{~m}$, and thus, a net displacement of 39 m (Simón et al., 2005; Lafuente et al., 2010a); taking into account the age error bars, this provides a slip rate of 0.22 to $0.35 \mathrm{~mm} / \mathrm{y}$. Other ages published by Gutiérrez el al. (2008) for the aforementioned tufa $(250+32 /$ 25 and $213+33 /-26 \mathrm{ka}$ ) are less reliable, since they come from two subsamples taken from a simgle sample. Nevertheless, introducing these values into the calculation would provide a slip rate range $(0.14-0.21 \mathrm{~mm} / \mathrm{y})$ which is still significantly higher than the overall rate since mid Pliocene times $(0.07-0.08 \mathrm{~mm} / \mathrm{y})$.

Data on slip rates since the Late Pleistocene are also available from the central sector of the fault (El Hocino site; see location in Fig. 4), where a pediment surface is apparently offset giving rise to a gentle, 5 to $5.5 \mathrm{~m}$ high topographic escarpment, later confirmed by trenching as a branch of the Concud fault (Lafuente et al., 2010b). The alluvial cover of the pediment has been dated by OSL (48.9 $\pm 4.4 \mathrm{ka}$; Table 1), although the artificial reworking (cultivation) of the uppermost deposits makes the result not completely reliable. A vertical slip rate of $0.09-0.12 \mathrm{~mm} / \mathrm{y}$ would be obtained, as a first approach, considering those data. Better constrained results have 
been obtained from trench $\mathrm{H} 1$, studied at this site (see section 3.4 and Fig. 5), where the lithologic unit representing the pediment cover in the hanging wall of the exposed fault (unit Q3) was recognized and dated. It lies in geometric continuity with the pediment surface at this block, and it is deformed into a roll-over geometry underlying a syntectonic, wedge-shaped sedimentary sequence. A fault throw of $5.5 \mathrm{~m}$ has been inferred in cross-section for this morpho-sedimentary marker. Considering that the dip of the fault surface is $60^{\circ} \mathrm{SW}$ (the lower apparent dip in the log of Fig. 5a results from obliqueness between the trench and the mean fault strike) and the measured pitch of the dominant fault striation is $75^{\circ} \mathrm{S}$, a net slip of $6.5 \mathrm{~m}$ can be approached. The age of the marker is bracketed between $77.3 \pm 4.3$ and $74.2 \pm$ $8.2 \mathrm{ka}$ OSL, probably closer to the latter (Lafuente et al., $2010 \mathrm{~b})$. The resulting net slip rate is comprised between 0.08 and $0.10 \mathrm{~mm} / \mathrm{y}$.

\subsection{General paleoseismological characterization}

Considering the visible surficial fault length $(14.2 \mathrm{~km})$ and its lack of segmentation, empirical correlations proposed by a number of authors (Wells and Coppersmith, 1994; Stirling et al., 2002; Pavlides and Caputo, 2004; Mohammadioun and Serva, 2001) can be used for estimating the moment magnitude of the maximum expected earthquake $\left(\mathrm{M}_{\mathrm{w}}\right)$ and its associated coseismic displacement (Table 2).

The estimated magnitudes $\mathrm{M}_{\mathrm{w}}$ from the distinct correlation models are quite similar, ranging from 5.74 to 6.98. These are in agreement with the occurrence of softsediment deformation structures in syntectonic (Middle and Upper Pleistocene), fine-grained fluvial deposits in the vicinity of the fault. Sand dykes, pillow and mushroom-like structures have been described and interpreted by Lafuente et al. (2008b) as a result of liquefaction

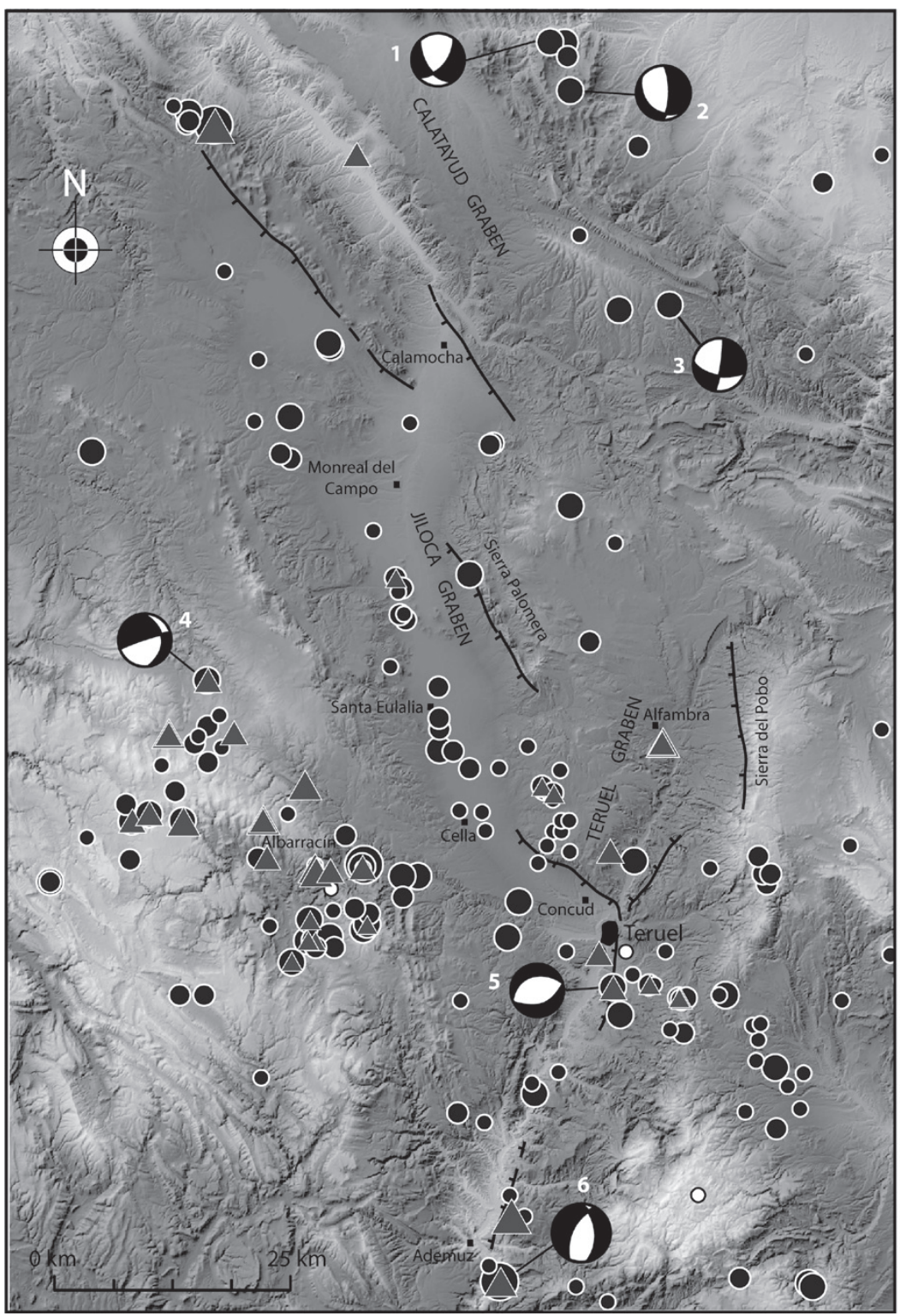

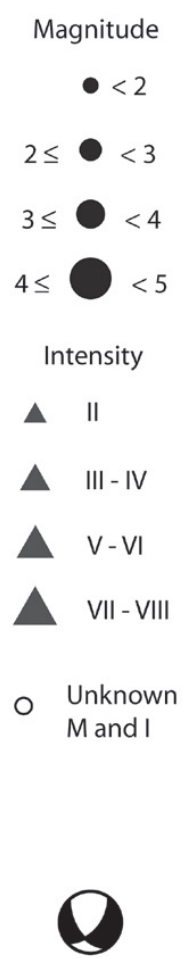

Focal mechanism
Fig. 3.- Historical and instrumental seismicity of the Teruel region.

Fig. 3.- Sismicidad histórica e instrumental de la región de Teruel. 


\begin{tabular}{cccccc}
\hline $\begin{array}{c}\text { Laboratory } \\
\text { reference }\end{array}$ & $\begin{array}{c}\text { Equivalent } \\
\text { dose (Gy) }\end{array}$ & $\begin{array}{c}\text { Anual dose } \\
\text { (mGy/yr) }\end{array}$ & $\begin{array}{c}\text { Supralinearity } \\
\text { (Gy) }\end{array}$ & $\begin{array}{c}\text { K } \\
\text { factor }\end{array}$ & $\begin{array}{c}\text { OSL age } \\
\text { (ka B.P.) }\end{array}$ \\
\hline MAD 5764SDA & $253.80 \pm 27.74$ & 3.63 & 0 & 0.22 & $69.917 \pm 5.479$ \\
MAD 5765SDA & $212.13 \pm 12.92$ & 2.79 & 0 & 0.13 & $76.032 \pm 5.005$ \\
MAD 5769SDA & $119.78 \pm 12.57$ & 2.45 & 0 & 0.08 & $48.889 \pm 4.365$ \\
\hline
\end{tabular}

Table 1.- New OSL dating results.

Tabla 1.- Nuevos resultados de dataciones por OSL.

processes triggered by seismic shocks of magnitude over 5-6.5 (depending on the type of structure), though under $\mathrm{M}_{\mathrm{w}}=7.5$.

With respect to the evaluation of mean coseismic displacements, it is noteworthy that the different correlations yield different values. We will see how the value estimated from Stirling et al. (2002) correlation $(2.06 \mathrm{~m})$ is closer to the observed displacements in our trenches. By combining this value with the calculated net displacements for different time intervals (see previous subsection), average recurrence intervals ranging from 5.9 to $9.4 \mathrm{ka}$ (or $14.8 \mathrm{ka}$, if considering ages published by Gutiérrez el al., 2008 for Los Baños site) can be estimated for post Middle Pleistocene times, and 24.7 to $25.5 \mathrm{ka}$ for the overall, post-Ruscinian fault activity.

\subsection{Trenching}

Trench studies have been carried out at two sites on the Concud fault trace: Los Baños and El Hocino (see location in Fig. 4). A succession of six large seismic events (probably seven), along a relatively continuous geologic record of Late Pleistocene age, has been identified at Los Baños trench (Fig. 6; Lafuente et al., 2010a). Event U is represented by the rupture and displacement (e.g. fault F0 in Fig 6d) of fluvial deposits (Middle Terrace) cropping out at the base of the sequence (units 1 and 2), and took place before the deposit of an unconformable sedimentary level (unit 3) dated at $71.7 \pm 5.2 \mathrm{ka}$. Event $\mathrm{V}$ is represented by a colluvial wedge (unit 4), developed on the downthrown block of fault F2 (Fig. 6d), which was then broken and displaced by fault $\mathrm{F} 1$ during event $\mathrm{W}$. The three youngest events $(\mathrm{X}, \mathrm{Y}$ and $\mathrm{Z}$ ) involved downthrow and tilting of units at the hanging wall, as well as development of three nested fissures filled with chaotic ensembles of conglomerate blocks coming from the Middle Pleistocene fluvial terrace. The two last fissure fills are dated at $38.6 \pm 2.3 \mathrm{ka}$ and $32.1 \pm 2.4 \mathrm{ka}$, respectively. An additional, hypothetical event X' has been inferred by Lafuente et al. (2010a) based on the existence of an 'extra' accommodation space for a sedimentary body (unit 9) prior to event Y. After discarding event U (probably representing more than one paleoseism), the remaining six events interpreted between $71.7 \pm 5.2$ and $32.1 \pm 2.4 \mathrm{ka}$ BP make a well time-constrained seismic succession that results in: (i) average recurrence interval of $6.6 \pm 1.3 \mathrm{ka}$; (ii) average net coseismic displacement of $2.0 \mathrm{~m}$ (Lafuente et al., 2010a); (iii) average slip rate of $0.25-0.37 \mathrm{~mm} / \mathrm{y}$.

At the El Hocino area, two trenches $(\mathrm{H} 1$ and $\mathrm{H} 2)$ were dug through a $5.5 \mathrm{~m}$-high topographic step, crossing the southern fault trace at the central sector. Both trenches show sands and red clays from the Rojo 2 unit (upper Turolien) in the footwall, that are affected by a shear zone up to $1.5 \mathrm{~m}$ wide, with $\mathrm{S}-\mathrm{C}$ foliation compatible with a normal sense of displacement. The hanging wall is composed by Pleistocene alluvial and slope deposits (units Q1 to Q7 in Fig. 5a). A total of five events have been interpreted (Lafuente et al., 2010b; Lafuente, 2011). According to our final interpretation (Lafuente, 2011), four of them (V, W, X and Y) appear in both trenches, whereas event $\mathrm{Z}$ is only evident in trench $\mathrm{H} 2$. Most of the events represent successive episodes of displacement in a footwall sequence, followed by erosion and fossilization of

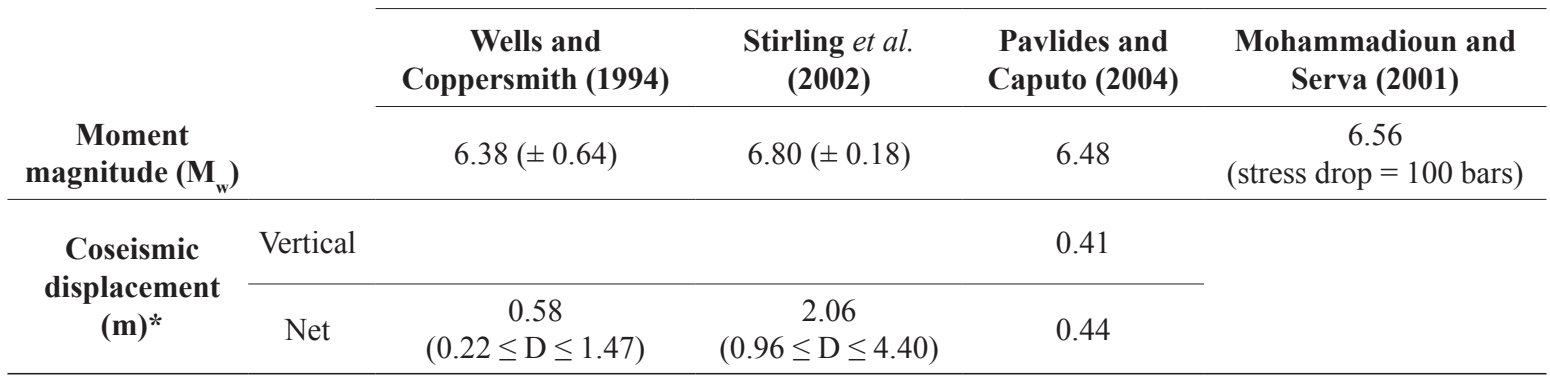

*The original Pavlides and Caputo (2004) equation refers to vertical displacement, we have transformed it to net displacement using fault dip and transport direction.

Table 2.- Estimation of moment magnitude and coseismic displacement for the Concud fault from empirical correlations.

Tabla 2.- Estimación de la magnitud momento y del desplazamiento cosísmico de la falla de Concud a partir de correlaciones empíricas. 


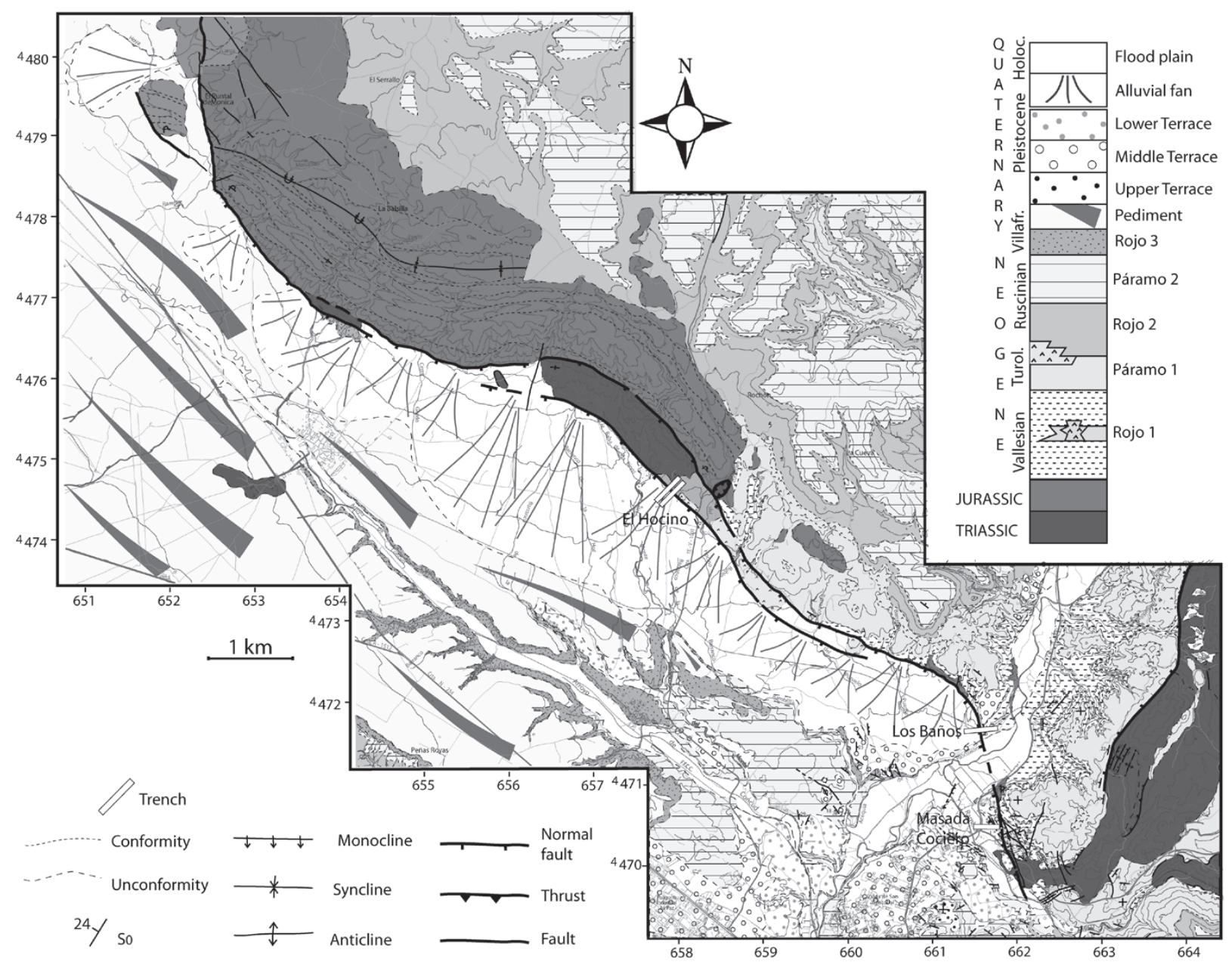

Fig. 4.- Geological map of the Concud fault and location of paleoseismological trenches (white rectangles).

Fig. 4.- Mapa geológico de la falla de Concud y localización de las trincheras de paleosismología (rectángulos blancos).

the paleoscarp during quiescence periods. The erosion surfaces constitute extremely useful markers because they postdate previous events, and then are displaced by later ones (Fig. 5a). The ages of the five events (see Table 3) are bracketed between, 81.6-66.6 ka (event V), 78.5$66 \mathrm{ka}$ (event W), 51.1-47.1 (event X), 46.8-37 ka (event $\mathrm{Y}$ ), and 21.6-20.3 (event $\mathrm{Z}$ ), which involves an average recurrence interval for the total paleoseismic succession of $(81.6-20.3) / 5=12.3 \mathrm{ka}$. The inferred net coseismic displacements range from 0.6 to $0.95 \mathrm{~m}$, with an average value of $0.8 \mathrm{~m}$ (Lafuente, 2011).

At least three of the events identified at El Hocino (W, $\mathrm{X}$ and $\mathrm{Y}$ ) correlate with some of the previously inferred in Los Baños trench, hinting at a consistent paleoseismic activity along the Concud fault. There are, then, some events present at Los Baños that are missing at El Hocino. This situation can be caused by a misinterpretation of their hypothetical evidences, by elimination by later events, or just because they never took place in the southern branch of the fault. Coseismic displacements inferred at El Hocino are smaller than at Los Baños, then again, there may be several explanations: i) an actual variation of displacement along the fault trace, ii) a partition of displacement between the northern and southern branches of the fault in its central sector, or iii) the occurrence of a creep component at El Hocino, as hinted by the shear zone within the footwall deposits.

Additional information is provided by another outcrop at the left side of the Alfambra valley, some $2 \mathrm{~km}$ north of Teruel, at the Masada Cociero site (see location in Fig. 4). On the artificial slope of the junction between roads $\mathrm{N}-420$ and A-226, a normal fault showing the same orientation of the Concud fault (about 150, $65 \mathrm{~W}$ ), interpreted as a minor branch fault of the former, offsets 1.7 to 2.2 $\mathrm{m}$ the base of the Lower Terrace deposits (Simón et al., 2005; Lafuente et al., 2011; Gutiérrez et al., 2011). This would represent the youngest movement recorded up to the present at the Concud fault, dated between $15.6 \pm 1.3$ and $14.9 \pm 1.0 \mathrm{ka}$ BP (Lafuente et al., 2008a).

If we consider the composite seismic succession from the four described trenches Table 3), we obtain a consistent seismic succession composed by nine events dated 
between 81.6 and 14,0 ka, with an average recurrence interval of $7.5 \mathrm{ka}$. From geological judgment, after criteria such as the relative timing of events or the relative position of the event horizon to the pre- and post-datum, we have approximated the most probable age of each event (right column in Table 3), which allows us to estimate individual interseismic periods ranging between 4 and $13 \mathrm{ka}$. The corresponding coseismic displacements range from 0.6 to $2.7 \mathrm{~m}$, resulting in an average slip rate of $0.25-0.27 \mathrm{~mm} / \mathrm{y}$ (Lafuente, 2011). These results are of the same order as the estimates from the correlation model of Stirling et al. (2002) obtained for post-Middle Pleistocene times (coseismic slip $=2.06 \mathrm{~m}$; average recurrence interval $=6.2-12.9$ ). The only exception is the small average coseismic slip at El Hocino $(0.8 \mathrm{~m})$, which suggests partitioning of the total activity among the southern and the northern branch of the fault.

\section{The Jiloca graben: Calamocha and Sierra Palomera faults}

The Calamocha and Sierra Palomera faults represent, together with the Concud fault, the master structures at the eastern boundary of the Jiloca graben (Fig. 2). The Calamocha fault cross-cuts the sedimentary infill of the Calatayud basin, which allows us to evaluate its recent offset. The base of the Lower Pliocene lacustrine carbonates at the top of the Neogene series (Páramo 2 unit; Hernández et al., 1983) lies, in its hanging wall, at about 860 m.a.s.1., in contact with Palaeozoic slates and Lower Miocene conglomerates of the footwall (Venta de los Céntimos; site 2 in Fig. 2). Although the same unit does not appear in the footwall close to this site, it could be either (a) approximately coeval of clastic deposits cropping out at Llano de la Lastra (site 3 in Fig. 2; Hernández et al., 1983), or (b) eroded while an unconformity underlying

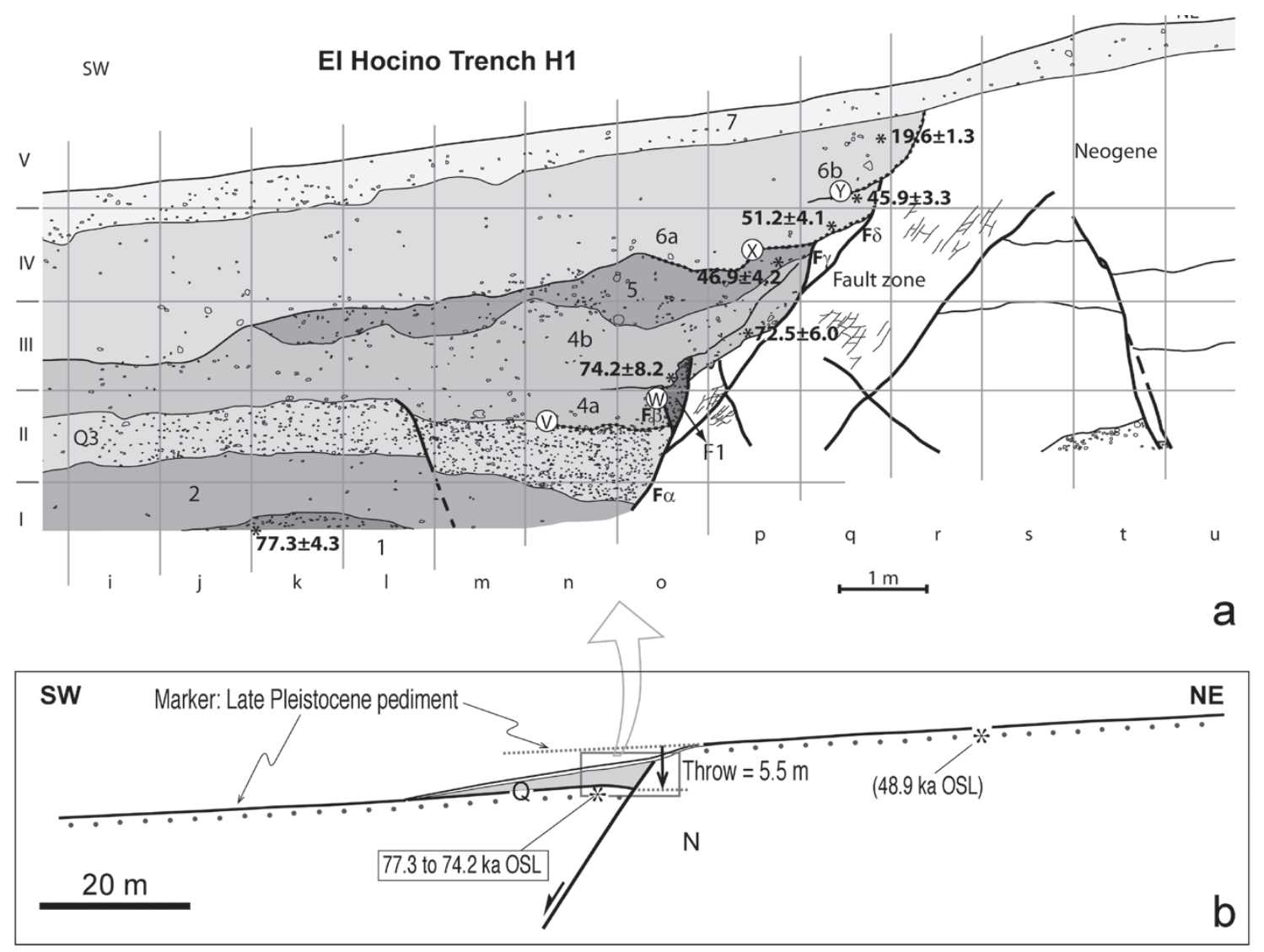

Fig. 5.- The Concud fault at El Hocino site. (a) Interpreted log of trench H1 (see location in Fig. 3); 1: non-cemented gravel made of angular pebbles; 2: silt and gravel; 3: gravel with carbonate cement; 4: silt wiht angular pebbles and uneven carbonate cement; 5: orange silt and gravel; 6: orange sand-silt with scattered pebbles; 7: surficial, anthropically reworked colluvium; units 4 and 6 are locally dividided into subunits ( $4 \mathrm{a}$ and $4 \mathrm{~b}, 6 \mathrm{a}$ and $6 \mathrm{~b}$ ) by erosive surfaces. (b) Schematic cross section that allows measuring the throw at the Late Pleistocene pediment; N: Neogene; Q: Quaternary including 'pre-tectonic' pediment cover (dotted), 'syn-tectonic' alluvial deposits (grey) and 'post-tectonic' slope deposits (white). See section 3.4 for more information.

Fig. 5.- La falla de Concud en El Hocino. (a) Interpretación del registro de la trinchera H1 (ver localización en Fig. 3); 1: grava no cementada de clastos angulosos; 2: limo y grava; 3: grava con cemento carbonatado; 4: limo con cantos angulosos y cementación carbonatada desigual; 5: limo ocre-anaranjado y grava; 6: arena-limo anaranjado con cantos dispersos; 7: coluvión superficial con retrabajado antrópico; las unidades 4 y 6 están divididas localmente en subunidades (4a y 4b, 6a y 6b) por sendas cicatrices erosivas. (b) Corte esquemático que muestra la medición del salto vertical en el glacis pleistoceno superior. 

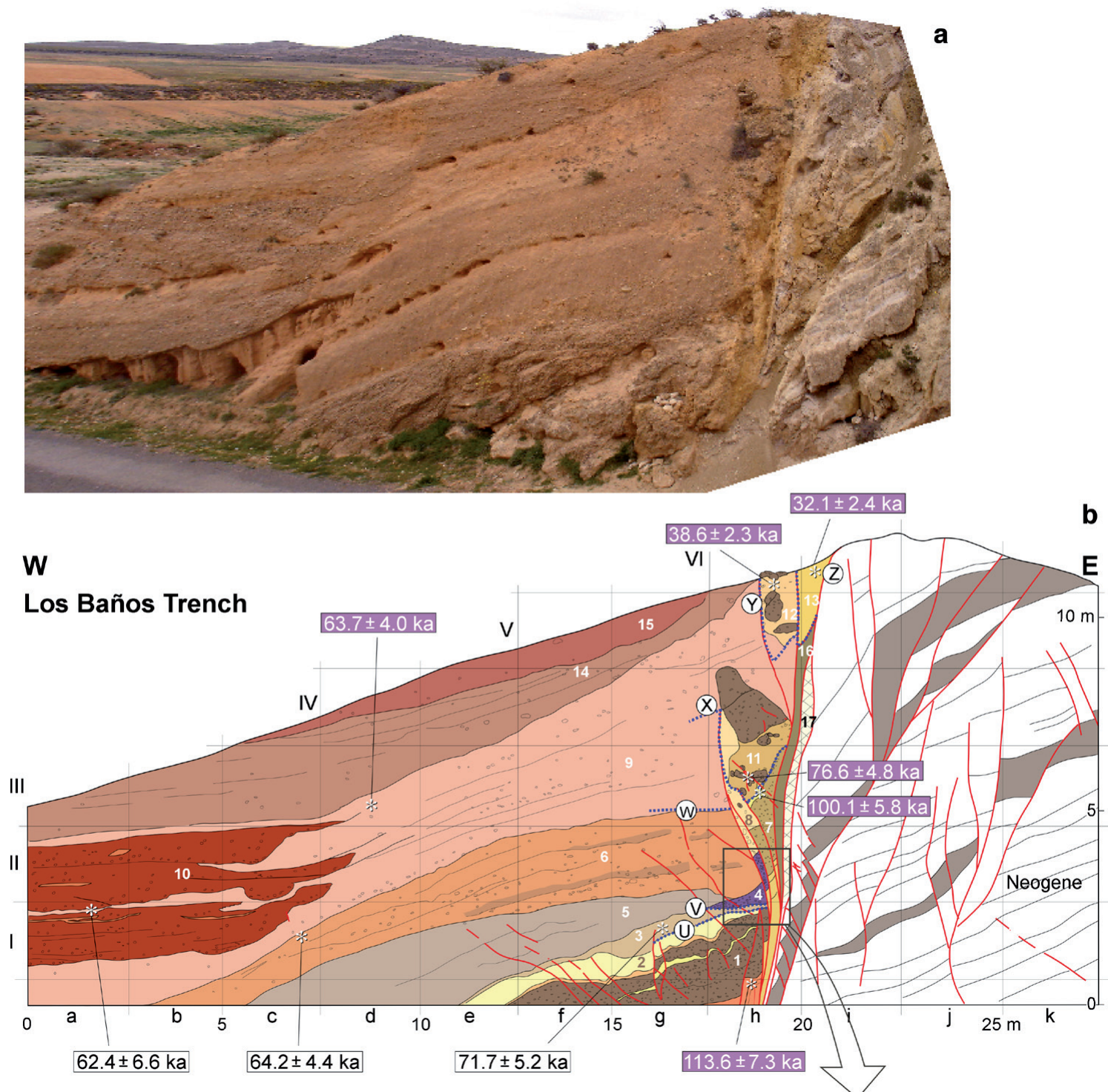

Fig. 6.- Paleoseismological analysis of the Concud fault at Los Baños trench (modified from Lafuente et al., 2010a, 2011; see location in Fig. 3). (a) Orthorectified field picture. (b) Trench log; 1: grain-supported conglomerate overlying fine sand and lutite; 2 : tufa; 3 : silt with tufa fragments; 4: colluvial wedge made of subrounded pebbles and cobbles; 5 and 6: sand and gravel with erosive bases; 7: narrow lutite slab pinched between faults; 8: gravel with sandy matrix; 9: thick colluvium made of gravel and pink sand; 10: gravel-sand channel facies; 11, 12 and 13: heterometric fissure fills; 14 and 15: sand-gravel colluvium; 16 and 17: fault breccia. OSL numerical ages: within shaded rectangles: after Lafuente et al. (2010a); within white rectangles: after Gutiérrez et al. (2008). (c) and (d) Detail of the relationships between faults F0, F1 and F2 and units 1 to 6, which allow to interpret events $\mathrm{U}, \mathrm{V}$ and $\mathrm{W}$.

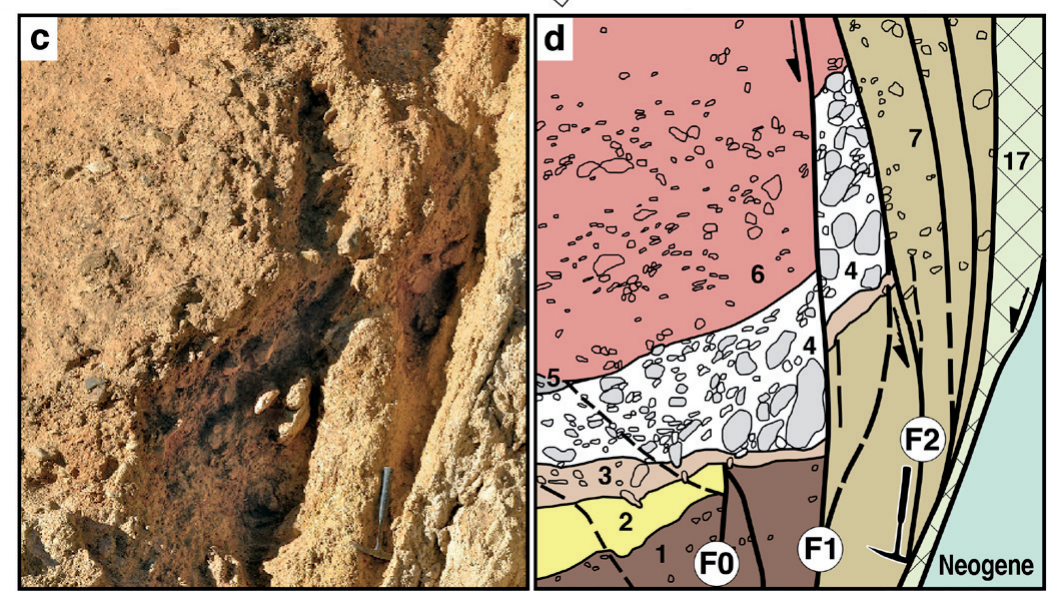

Fig. 6.- Análisis paleosismológico de la falla de Concud en la trinchera de Los Baños (ver localización en Fig. 3). (a) Fotografía de campo ortocorregida. (b) Corte de detalle de la trinchera; 1: conglomerado granosostenido sobre niveles de arena fina y lutita; 2: toba calcárea; 3: limo con fragmentos de toba; 4: cuña coluvial formada por cantos subredondeados; 5 y 6: arena y grava con bases erosivas; 7 : laja de lutita pinzada entre fallas; 8: grava de matriz arenosa; 9: coluvión de grava y arena rosada; 10: facies de canal de grava y arena; 11, 12 y 13: rellenos de fisuras heterométricos; 14 y 15: coluviones de arena y grava; 16 y 17: brecha de falla. Edades absolutas por OSL: rectángulos sombreados: según Lafuente et al. (2010a); rectángulos blancos: según Gutiérrez et al. (2008). (c) y (d) Detalle de las relaciones entre las fallas F0, F1 y F2 y las unidades 1 a 6 , que permiten interpretar los eventos $\mathrm{U}, \mathrm{V} \mathrm{y} \mathrm{W.}$ 
Table 3.- Sequence of the seismic events recorded in the ensemble of trenches studied at the Concud fault.

Tabla 3.- Sucesión de eventos sísmicos registrados en el conjunto de las trincheras estudiadas en la falla de Concud.

\begin{tabular}{|c|c|c|c|c|c|c|c|}
\hline \multirow{2}{*}{ Event } & \multicolumn{2}{|c|}{ Los Baños trench } & \multicolumn{2}{|c|}{ El Hocino trenches } & \multicolumn{2}{|c|}{ Masada Cociero trench } & \multirow{2}{*}{$\begin{array}{l}\text { Estimated } \\
\text { age (ka) }\end{array}$} \\
\hline & predatum $(\mathrm{ka})$ & postdatum (ka) & predatum (ka) & postdatum (ka) & predatum (ka) & postdatum (ka) & \\
\hline 1 & $\begin{array}{c}120.9 \\
(113.6 \pm 7.3)\end{array}$ & $\begin{array}{c}66.5 \\
(71.7 \pm 5.2)\end{array}$ & $\begin{array}{c}\mathbf{8 1 . 6} \\
(77.3 \pm 4.3)\end{array}$ & $\begin{array}{c}\mathbf{6 6 . 6} \\
(71.3 \pm 4.7)\end{array}$ & & & $72-74$ \\
\hline 2 & $\begin{array}{c}76.9 \\
(71.7 \pm 5.2)\end{array}$ & $\begin{array}{c}58.9 \\
(64.2 \pm 4.4)\end{array}$ & $\begin{array}{c}78.5 \\
(72.5 \pm 6.0)\end{array}$ & $\begin{array}{c}66 \\
(74.2 \pm 8.2)\end{array}$ & & & $68-70$ \\
\hline 3 & $\begin{array}{c}68.6 \\
(64.2 \pm 4.4)\end{array}$ & $\begin{array}{c}59.7 \\
(63.7 \pm 4.0)\end{array}$ & & & & & 64 \\
\hline 4 & $\begin{array}{c}68.6 \\
(64.2 \pm 4.4)\end{array}$ & $\begin{array}{c}59.7 \\
(63.7 \pm 4.0)\end{array}$ & & & & & 60 \\
\hline 5 & $\begin{array}{c}67.7 \\
(63.7 \pm 4.0)\end{array}$ & $\begin{array}{c}36.3 \\
(38.6 \pm 2.3)\end{array}$ & $\begin{array}{c}\mathbf{5 1 . 1} \\
(46.9 \pm 4.2)\end{array}$ & $\begin{array}{c}47.1 \\
(51.2 \pm 4.1)\end{array}$ & & & $47-51$ \\
\hline 6 & & $\begin{array}{c}36.3 \\
(38.6 \pm 2.3)\end{array}$ & $\begin{array}{c}46.8 \\
(43.8 \pm 3.0)\end{array}$ & $\begin{array}{c}37 \\
(40.4 \pm 3.4)\end{array}$ & & & $39-41$ \\
\hline 7 & & $\begin{array}{c}29.7 \\
(32.1 \pm 2.4)\end{array}$ & & & & & 32 \\
\hline 8 & & & $\begin{array}{c}21.6 \\
(19.5 \pm 2.1)\end{array}$ & $\begin{array}{c}20.3 \\
(22.3 \pm 2.0)\end{array}$ & & & 21 \\
\hline 9 & & & & & $\begin{array}{c}16.9 \\
(15.6 \pm 1.3)\end{array}$ & $\begin{array}{c}14.0 \\
(15.0 \pm 1.0)\end{array}$ & 15 \\
\hline
\end{tabular}

those clastic deposits was developed. This unconformity lies at 1060-1080 m.a.s.l., which would approach a throw of 200-220 m (net displacement of 215-235 m, considering a measured $70^{\circ} \mathrm{W}$ fault dip) for the Calamocha fault. Hernández et al. (1983) had proposed a displacement of $250 \mathrm{~m}$, as well. Assuming for the top of the Páramo 2 unit the same age as in the Concud-Celadas area (latest Ruscinian; 3.6 Ma), and assuming that the entire offset is later, the resulting average vertical slip rate would be $0.06-0.07 \mathrm{~mm} / \mathrm{y}$.

Quaternary activity of the Calamocha fault is evidenced by the mechanical contact of Neogene units against the red alluvial Pleistocene deposits that infill the northernmost Jiloca basin. The traces of two branches of the fault are well exposed at the slopes of the Autovía Mudéjar (A23, $\mathrm{km} \mathrm{186),} \mathrm{some} 2 \mathrm{~km}$ east of Calamocha. The northern trace separates the lowermost Neogene unit (Lower Miocene lutites and carbonates) from Mio-Pliocene (?) lutites. The southern one, which also crops out at a neighbouring industrial area, separates the latter from Pleistocene alluvial deposits. The uppermost alluvial level in contact with the fault surface has an OSL age of $69.9 \pm$ $5.5 \mathrm{ka} \mathrm{BP}$ (Table 1).

In the central segment of the Jiloca depression, the offset at the Sierra Palomera fault cannot be calculated in the same way as the Concud and Calamocha faults, since no appropriate recent sedimentary marker can be recognized in both walls, and it is very difficult to estimate the structural throw in the folded Jurassic units. Nevertheless, as discussed by Rubio and Simón (2007), there are two arguments that support the notion of a recent displacement of the Sierra Palomera fault larger than those of Calamocha and Concud faults, which would be consistent with a common structural pattern of segmented extensional fault zones, in which the displacement profile of the overall structure (throw decreasing from centre to tips) is self-similar with those of individual faults (Cowie and Roberts, 2001). First, the morphologic scarp is higher (up to $300 \mathrm{~m} ; 450 \mathrm{~m}$ for the whole mountain front; Fig. 7) than those of Calamocha and Concud faults. Second, the eastern wall of the Sierra Palomera fault is a tilted block whose outline is defined by the FES and, eastwards, by the uppermost lacustrine carbonate deposits of the Teruel basin (Early Pliocene in age: Godoy et al., 1983b); both are in continuity with each other and show a quite homogeneous slope of about $2 \%$ along a distance of 18 $\mathrm{km}$. The height of this morpho-sedimentary marker varies from $1060 \mathrm{~m}$ (Alfambra valley) to $1480 \mathrm{~m}$ (Sierra Palomera), which involves a tectonic uplift of the Sierra Palomera block of about $420 \mathrm{~m}$ relative to the bottom of the Teruel depression. This value closely approaches the amplitude of the next morphostructural step to the west, i.e. the Sierra Palomera mountain front, since the lowest mapped remnants of the FES near the bottom of the Jiloca graben, southwest of Santa Eulalia (Peña et al., 1984), again lie at altitudes of 1040-1080 m.a.s.l. In our opinion, the resulting height difference of 400-440 m represents a reliable approach to the total recent extensional throw of the Sierra Palomera fault.

Additionally, if we consider subsoil data on the NeogeneQuaternary infill of the Jiloca basin (Rubio and Simón, 2007), we can interpret that the boundary between the red alluvial Plio-Pleistocene deposits and an underlying carbonate unit represents the regional contact of informal units Páramo 2 and Rojo 3, i.e. correlates with either the FES or the $S 2$ surface. Such boundary lies at about 940 950 m.a.s.l. in the Santa Eulalia area (some 40-50 below the ground surface). The total vertical offset associated to 
the eastern boundary of the Jiloca graben would therefore increase up to 530-540 $\mathrm{m}$. Assuming the formerly used age of the lacustrine carbonates $(3.6 \mathrm{Ma})$ as representative for the whole stratigraphical-geomorphological marker, the resulting average vertical slip rate would range from 0.11 to $0.15 \mathrm{~mm} / \mathrm{y}$.

The Plio-Quaternary alluvial and palustrine infill of the central Jiloca depression shows varying thickness, usually ranging from 20 to $60 \mathrm{~m}$ and locally exceeding $75 \mathrm{~m}$. Such variations are in part controlled by NW-SE striking faults at the western basin boundary (Santa Eulalia and Cella faults), which suggests synsedimentary activity. Poorquality outcrops at a number of gullies crossing the Sierra Palomera fault also show indices of mechanical contacts between Jurassic limestones and alluvial Quaternary deposits. The existence of active alluvial fans, neither incised nor connected to the present-day fluvial network is consistent with the hypothesis of recent Quaternary activity.

\section{The Teruel graben: Sierra del Pobo and Teruel faults}

The northernmost sector of the Teruel basin is a halfgraben bounded by an important N-S striking fault that separates the basin from the Sierra del Pobo (Fig. 8). This fault controls the onset of the halfgraben, its infill, and tilting of the intra-Pliocene FES between Sierra Palomera and the Alfambra valley. In a first approach, a structural offset of about $700 \mathrm{~m}$ can be estimated for the whole Sierra del Pobo mountain front seeing at the height of the Jurassic units at both sides of the fault, though some component of continuous deformation cannot be discarded. Casas and Cortés (2002) consider that Sierra del Pobo and the Alfambra basin compose an anticline-syncline system indeed, although we believe that faulting is responsible for the main component of tectonic offset. This is clearly observed within Mesozoic units outcropping at the Sierra del Pobo mountain front (Liesa, 2011) and, less remarkably, within Neogene sediments of the basin.

Late Neogene erosion surfaces are again useful markers for assessing the overall recent activity of the fault. In all likelihood, Sierra del Pobo was never leveled by the FES (Moissenet, 1980), so its summit (Hoyalta, $1760 \mathrm{~m}$ ) does not correlate with the top of Mio-Pliocene syntectonic sediments. However, the erosion surface developed northwards and eastwards, at altitudes usually ranging from 1450 to 1500 m.a.s.l., could be feasibly identified with the FES. In such a case, an approximate post-Lower Pliocene vertical displacement of $400 \mathrm{~m}$ could be inferred, remarkably similar to the difference in altitude between the far ends of the Alfambra tilted block. A larger offset could be estimated for the Intra-Miocene Erosion Surface, buried at 1050 m.a.s.l. in the hanging wall (representing the base of the Miocene sequence in the Alfambra-Perales area; Gutiérrez and Peña, 1976) and capping the Sierra del Pobo in the footwall (1760 m) (Pailhé, 1984; Sánchez Fabre, 1989). The obtained value $(710 \mathrm{~m})$ closely approach the aforementioned total structural offset in Jurassic units. This scenario allows us to infer average vertical slip rates of about $0.11 \mathrm{~mm} / \mathrm{y}$ for the post-Early Pliocene period $(400 \mathrm{~m}, 3.6 \mathrm{Ma})$, and $0.06 \mathrm{~mm} / \mathrm{y}$ for the whole Late Miocene-Present day lapse $(710 \mathrm{~m}, 11.1 \mathrm{Ma})$. Although deformed Pleistocene deposits are frequently observed in the hanging wall, no correlation with equivalent deformed markers in the footwall has been achieved in order to calculate slip rates during this period.

The Teruel fault is a nearly pure normal fault located inside the central sector of the Teruel graben, which cuts its Mio-Pliocene infill along a N-S trending, 9-km long trace (Fig. 2). The hanging wall (to the west) is structured as a roll-over that descends the Ruscinian limestones (Páramo 2 unit, 3.6 Ma) some $140 \mathrm{~m}$ : its base is at 1020 m.a.s.l. on the La Muela hill top (site 4 in Fig. 2), and down under 880 $\mathrm{m}$ at Teruel. On the footwall (Los Mansuetos platform, to the east of Teruel; site 5 in Fig. 2), the base of Páramo 2 unit is at 1080 to 1100 m.a.s.l., which involves a vertical displacement of 200-220 m. Considering an average measured dip of $68^{\circ}$ and pure normal displacement, that implies a net slip of $215-235 \mathrm{~m}$ and an average slip rate of about $0.06 \mathrm{~mm} / \mathrm{y}$. This displacement was not accommodated solely by brittle fracturing; the structure includes some ductile component as well, expressed in the lutitic Rojo 1 unit as a bending monocline trending N-S and dipping up to $17^{\circ}$ (northern sector) or $30^{\circ}$ (southern sector).

The Teruel fault shows scarce, not explicit evidences of Quaternary activity. Remnants of the Upper Terrace of the Turia river have been mapped on the hanging wall west of Teruel "La Muela" (Peña, 1981; Godoy et al., 1983a), at an altitude of 970-980 m.a.s.1.. Moissenet (1983) identified the same terrace level at a limited outcrop east of Teruel (Casas de Urrez; site 6 in Fig. 2), at 1017 m.a.s.l., and therefore interpreted a post-Upper Terrace vertical offset of about $40 \mathrm{~m}$. At Puntal de Pitraque (site 7 in Fig. 2), some $1.5 \mathrm{~km}$ south of Teruel town, two separate remnants of fluvial deposits that can be attributed to the Middle Terrace are offset $9 \mathrm{~m}$ by a branch of the Teruel fault (Fig. 9). The base of the fluvial sequence has been dated by means of OSL in $76.0 \pm 5.0 \mathrm{ka}$ (see Table 1), an age that fits well that previously given for the lower sublevel of the Middle Terrace in the Teruel area $(91 \pm 5 \mathrm{ka}$; Lafuente et al., $2008 \mathrm{~b}$ ). The obtained vertical slip rate is $0.11-0.13 \mathrm{~mm} / \mathrm{y}$. Since this displacement is recorded only on one among three fault branches into which the Teruel fault splits at this area, the total slip rate for the overall structure during 


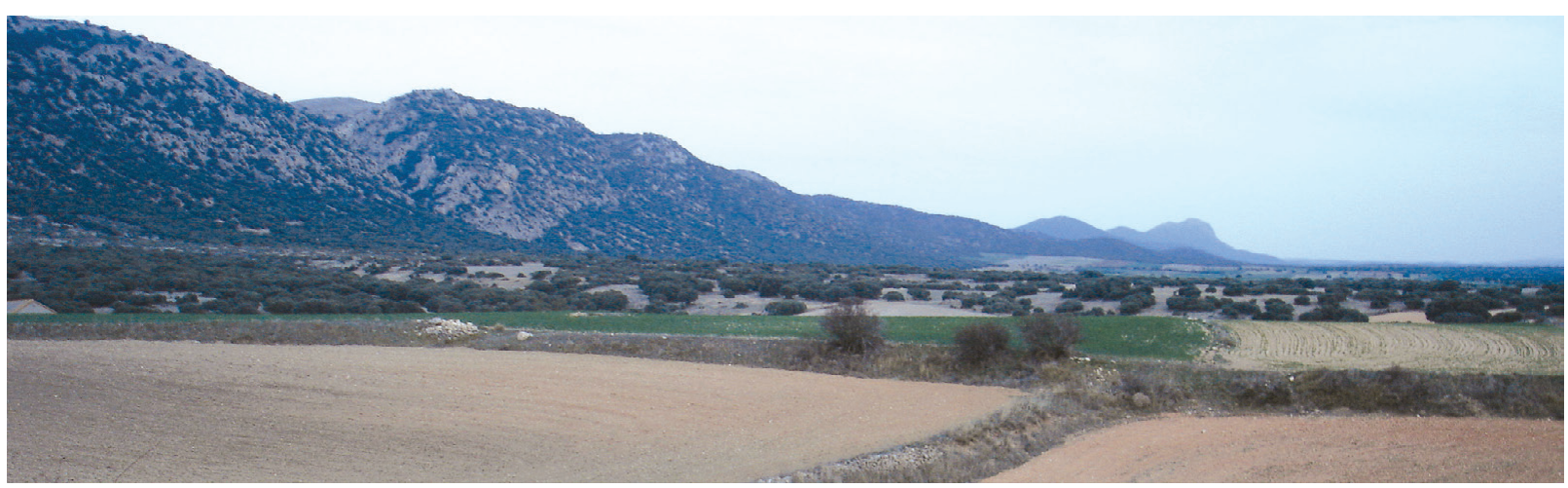

Fig. 7.- Panoramic view of the Sierra Palomera fault mountain front.

Fig. 7.- Vista panorámica del escarpe de la falla de Sierra Palomera.

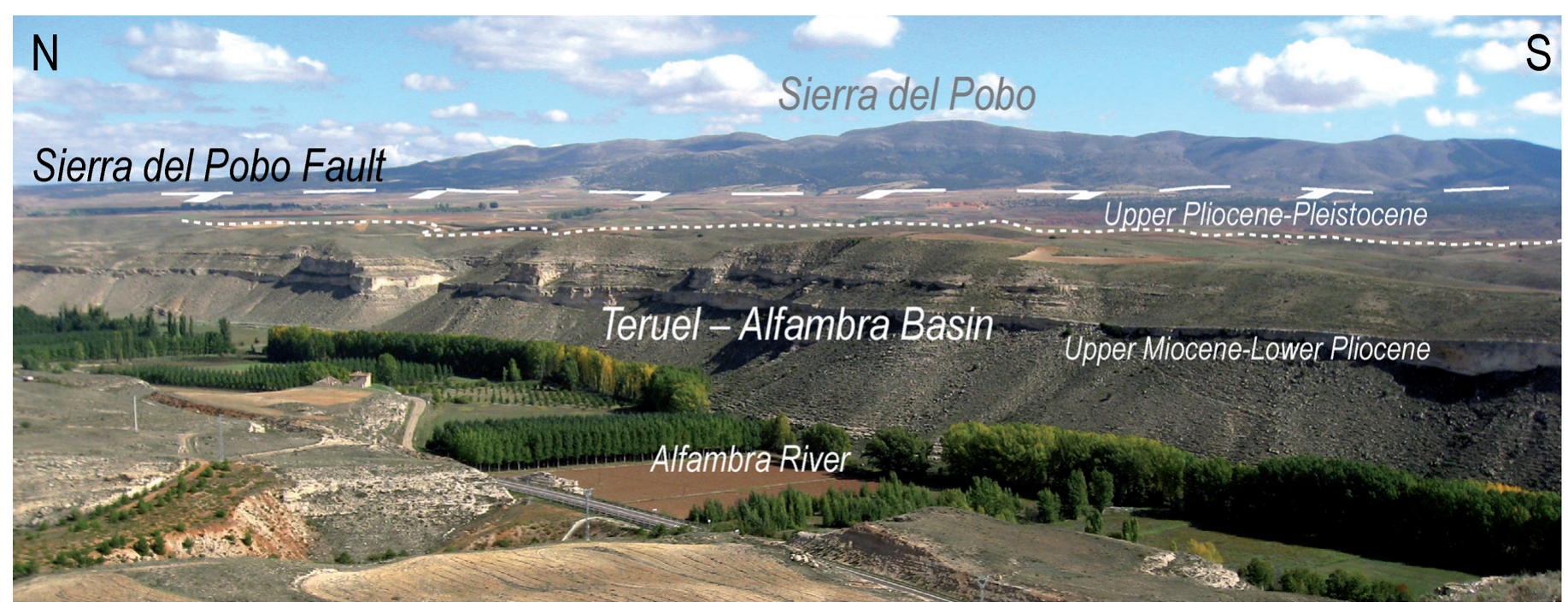

Fig. 8.- Eastern boundary of the Alfambra-Teruel basin, northern sector: Sierra del Pobo fault.

Fig. 8.- Margen oriental de la fosa de Alfambra-Teruel, sector norte: falla de la Sierra del Pobo.

Late Pleistocene-Holocene times could be higher than this value. The absence of involved Quaternary deposits at the eastern branch (out of Fig. 9) makes impossible to test such hypothesis.

\section{Maestrat grabens: Rambla de la Viuda, Coves de Vinromà and Alcalà de Xivert-Irta faults}

The Maestrat grabens are the easternmost extensional structures in the Iberian Chain. A number of parallel, NNE-SSW trending grabens and horsts extend up to 30$35 \mathrm{~km}$ from the Mediterranean coast, giving rise to a conspicuous 'basin and range' landscape (Fig. 10a). Vertical displacements of decametre to hectometre scale occurred on a number of large faults of the Maestrat grabens by the Early-Middle Pleistocene, interacting with the fluvial landscape and inducing significant changes on it (Pérez and Simón, 1993). Nevertheless, their morphotectonic analysis (Perea, 2006) and geological evidences suggest that they do not show a level of activity as higher as that of the Teruel grabens. The better documented active faults are the Rambla de la Viuda fault, the Torre Endomènech and La Valltorta faults (western boundary of the Coves de Vinromà graben), and the Xivert, Irta and Torreblanca faults (near the coast) (Fig. 10b).

Their evolution can be constrained based on the relationships between faulting and morphogenic episodes. After the development of the FES, the geomorphic and sedimentary evolution of the Maestrat grabens has been characterized by a sequence of three erosional-depositional levels whose development closely interacts with Plio-Pleistocene tectonic activity. They are expressed in most areas as nested erosion levels (pediments, fluvial terraces), whereas in others (those undergoing more rapid subsidence) they give rise to superposed sedimentary units. According to the nomenclature proposed by Simón (1982) and Simón et al. (1983), these levels are designed, in chronological order, as G3, G2-T2 and G1T1 (Fig. 10b). Deposits associated to G3 (characteristic gravel made of rounded pebbles and cobbles) can be cor- 


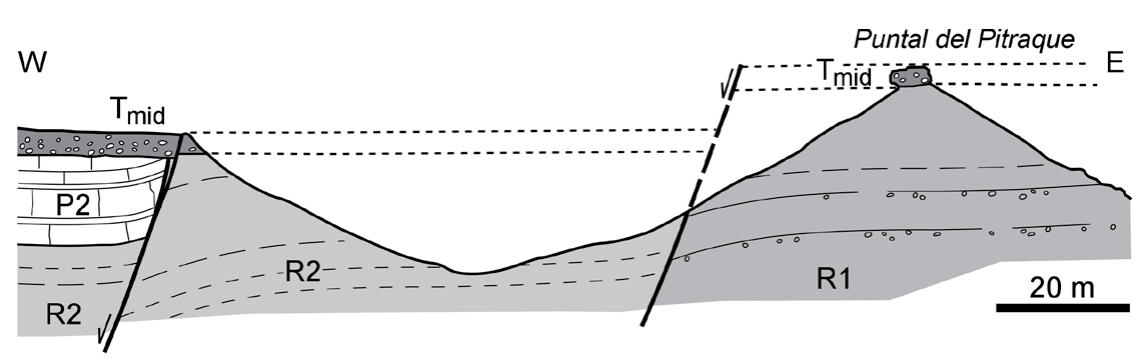

Fig. 9.- Schematic cross section of the western branch of the Teruel fault at the Puntal de Pitraque sector showing the Middle Terrace $\left(\mathrm{T}_{\text {mid }}\right)$ offset. See location in Fig. 2. Fig. 9.- Corte esquemático de la rama occidental de la falla de Teruel en la zona del Puntal de Pitraque, mostrando el desplazamiento de la Terraza Media. Ver localización en Fig. 2. related with the regional Villafranchian pediment system. The G2-T2 geomorphic level is represented by either the top of alluvial sediments filling grabens and coastal plains (Catí, Rambla de la Viuda, Tírig, Coves de Vinromà, Torreblanca), or by erosive incisions; their age is broadly attributed to the Early-Middle Pleistocene based upon regional correlation with fluvial terraces of the Ebro Basin (Birot, 1959; Simón, 1982). Fluvial and alluvial gravel and silt of the G1-T1 level can be attributed to the Late-Pleistocene based on the existence of abundant Aurignacian lithic industry within the lower terrace of the Mijares River, south of the studied region (Birot, 1959).

The Rambla de la Viuda fault forms the prominent mountain front that separates Serra d'Engalcerán horst from Rambla de la Viuda graben (Fig. 10b), showing an undulate, nearly N-S trending trace. The fault surface is exposed at Barranc de la Guitarra, south of Los Rosildos village, showing local orientation $030,68^{\circ} \mathrm{W}$. At this site, the fault separates Cretaceous limestones from Pleistocene conglomerates belonging to an alluvial fan whose surface correlates with G2-T2. The lowermost outcropping alluvial beds, $1 \mathrm{~km}$ west of the fault trace, dip 20$25^{\circ} \mathrm{E}$ (i.e. against the mountain front), whereas younger beds to the east become nearly horizontal or dip about $2-3^{\circ} \mathrm{E}$ (parallel to the fan surface). This suggests that the fault was active while alluvial sedimentation took place, producing a gentle progressive unconformity in the hanging wall (Simón, 1982). The difference in height between remains attributed to the FES at the neighbouring Serra d’Engalcerán summit (1040-1060 m.a.s.1.; Simón, 1982) and the bottom of the graben at this area (420 m.a.s.1.) allows us to approach a total fault throw of 620-640 m that should be mostly accommodated by the Rambla de la Viuda fault. The erosion surface has no local age constraint, since correlative lacustrine deposits have not been found within the Maestrat sector. We hypothesize that it could correspond to either the S2 (Late Turolian, 5.0 Ma) or the S3 surface (latest Ruscinian, 3.6 Ma) of the Teruel basins. This would result in an average net slip rate of $0.12-0.18 \mathrm{~mm} / \mathrm{y}$ for the whole period of recent activity of the fault. Unfortunately, no dated marker is available that could approach specific slip rates for Quaternary times.

Two faults at the western boundary of the Coves de Vinromà graben (Fig. 10b), the Torre Endomenech and
La Valltorta faults, produce decametric offset of the G3 pediments (Simón, 1982). For the first one, this can be observed 2-4 km southwest of Torre Endomenech, where the G3 alluvial deposits appear on two distinct topographic levels separated by a 40-m high step. A higher step $(50-70 \mathrm{~m})$ separates an erosive sector of the G3 pediment from the top of the correlative sediments (to the east) at both margins of Barranc de la Valltorta, $4 \mathrm{~km}$ southeast of Tirig. Assuming that the age of G3 is similar to that of the Villafranchian pediments of the Teruel area, dated at La Puebla de Valverde both by macromammal fauna (Adrover, 1975; MN17 zone, 1.9-2.6 Ma) and magnetostratigraphy (1.95-2.1 Ma; Sinusía et al., 2004), the corresponding average vertical slip rates during Quaternary times for both faults would be in the range of 0.02-0.04 $\mathrm{mm} / \mathrm{y}$.

The western boundary of the Alcalà de Xivert graben is related with a NNE-SSW striking normal fault that crops out at the CV-133 local road, some $2.5 \mathrm{~km}$ west of Alcalà de Xivert, where it produces a sharp drag-fold in the Lower Miocene marly limestones. The eastern boundary of the graben is another NNE-SSW normal fault (Xivert fault; Fig. 10b), which separates it from the Irta range, a large horst whose western branch conserves remnants of the FES at 370-390 m.a.s.l. (Simón, 1982). The bottom is modeled by the G3, mainly erosive pediment level (Fig. $10 \mathrm{~b}$ ) at about 160-180 m.a.s.l., showing several embayments entering the footwall and no evidence of later faulting. This suggests that the Xivert fault essentially moved during Pliocene times and has remained virtually inactive during the Quaternary. Assuming the FES on the hanging wall probably lay little higher than the erosive G3 surface, a vertical offset close to $200 \mathrm{~m}$ can be estimated. If we consider the joint activity with a synthetic fault to the east (Irta fault) and the height of the interpreted FES on the eastern Serra d'Irta branch (490-570 m.a.s.1.), the total vertical displacement between the Irta horst and the Alcalà de Xivert graben could attain 300-350 m. It implies a slip rate for the Xivert fault of $0.06-0.1 \mathrm{~mm} / \mathrm{y}$ for the last 3.6-5.0 Ma.

The Ametler graben is a small depression that divides the Irta range into two branches (Fig. 10b), with its bottom gently dipping from north (180 m.a.s.1.) to south (100 m.a.s.1.). It shows a sedimentary infill mainly made 


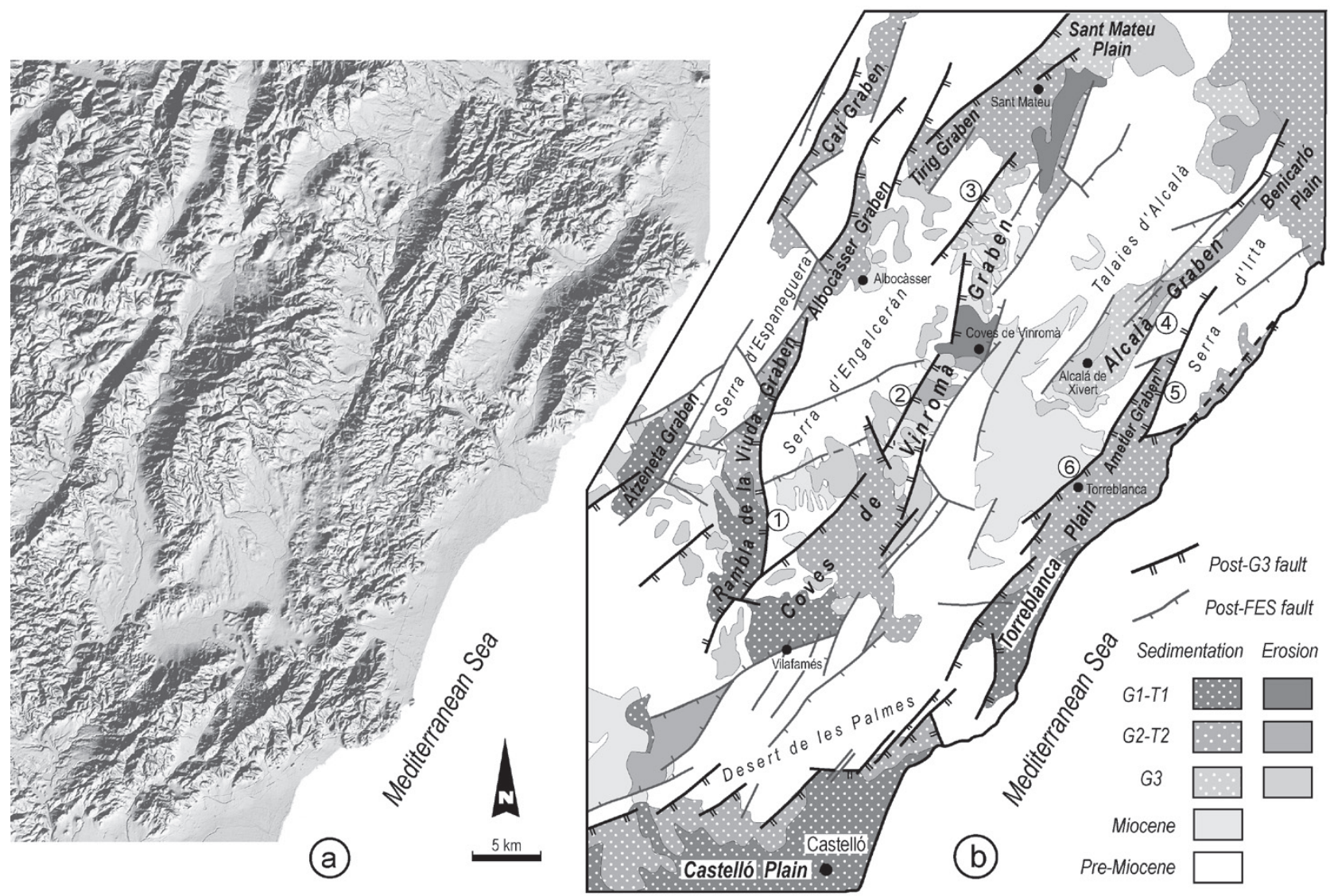

Fig. 10.- Maestrat grabens (see location in Fig. 1). (a) Digital Elevation Model. (b) Geological map. 1, Rambla de la Viuda fault; 2, Torre Endomènech fault; 3, La Valltorta fault; 4, Xivert fault; 5, Irta fault; and 6, Torreblanca fault. See the text for more information of the sedimentary units.

Fig. 10.- Fosas del Maestrat (ver localización en Fig. 1). (a) Modelo Digital de Elevaciones. (b) Mapa geológico. 1, falla de la Rambla de la Viuda; 2, falla de Torre Endomènech; 3, falla de La Valltorta; 4, falla de Xivert; 5, falla de Irta; y 6, falla de Torreblanca. Ver texto para más información de las unidades sedimentarias.

of alluvial fans coming from the eastern margin, whose top is levelled, together with the northern sector of the Torreblanca coastal plain, by the G2 surface. The eastern fault bounding the graben (Irta fault) runs through the Irta horst and is responsible for the development of the aforementioned alluvial fans. While the Xivert fault seems to have moved only during the Pliocene, the Irta fault remained active during the Pleistocene. The western margin of the Ametler graben corresponds to the northern segment of the Torreblanca fault (their central and southern segments limit the whole Torreblanca coastal plain). This fault beheads two ancient valleys whose lowest segments make pronounced embayments at the western Irta mountain front, and whose original heads were probably located at the axis of the present-day eastern Irta range. This fault produced a complete inversion of the relief, sinking the narrow Ametler graben at the middle of the Irta range. This interpretation has been tested by applying geomorphic analysis and considering surface and subsoil information about the sedimentary infill (Salvador and Simón, 1990). Such scenario allows us to ap- proach the average Quaternary slip rate of the northern Torreblanca fault, assuming the formerly hypothesized age for G3 (1.9-2.6 Ma). The fault throw can be estimated from surface and subsoil data, provided by Salvador and Simón (1990), concerning the position of the base of the Pleistocene infill (i.e. the buried paleo-topography of the middle segments of the beheaded valleys), which lies at 130-140 m.a.s.l. at the supposed paleo-talwegs east of the Portell present-day head. In absence of faulting, if we extrapolate hypothesized fluvial profiles from the remaining lower segments to the Serra d'Irta heads, such paleo-talwegs at the surveyed transect should lie around 230-250 m.a.s.1. This results in an estimated vertical offset of 90-100 m and an average post-G3 slip rate of 0.03$0.05 \mathrm{~mm} / \mathrm{y}$.

\section{Discussion and conclusions}

The main active faults in the central-eastern Iberian Chain are normal faults with dominant directions NNESSW and NNW-SSE, and hectometre-scale vertical off- 
sets during Late Miocene-Quaternary times (Table 4). Their average slip rates since Late Neogene times (3.6 to $5.0 \mathrm{Ma}$ ) are comparable for a number of large faults, higher for Sierra Palomera, Sierra del Pobo and Rambla de la Viuda faults $(0.11-0.18 \mathrm{~mm} / \mathrm{y})$, and lower for the Concud, Calamocha, Teruel and Xivert faults (0.06-0.10). In contrast, results from the Pleistocene record show how the Concud fault is noticeably more rapid.

Slip rates at the Concud fault are comparable to those calculated for normal faults of the Betic Chains, as the Granada (0.03-0.38 mm/y; Sanz de Galdeano et al., 2003), Ventas de Zafarraya $(0.3-0.45 \mathrm{~mm} / \mathrm{y}$ during Holocene times; Reicherter et al., 2010), or Baza fault (0.12-0.33 $\mathrm{mm} / \mathrm{y}$; García-Tortosa et al., 2008; Alfaro et al., 2008). In contrast, the Concud fault moves at higher rates than El Camp fault $(0.02 \mathrm{~mm} / \mathrm{y}$; Masana et al., 2001). Perhaps, the Concud fault could appear as anomalously rapid during Pleistocene times, seeing at its regional tectonic and seismic framework (overall gentle deformation and very low instrumental seismicity). It may be difficult to assume that their slip rates are similar to those calculated at extensional faults of a much more active region as the Betic Chains. The explanation probably deals with the particular tectonic position and role of the Concud fault. While at southeastern Betics the total crustal deformation is distributed among a number of large faults, no other fault at the central-eastern Iberian Chain has any evidence of continuous activity during Middle-Late Pleistocene times comparable to the Concud fault. Regional deformation during the Plio-Pleistocene transition was

\begin{tabular}{|c|c|c|c|c|c|c|}
\hline & Faults & Marker & Time lapse & $\begin{array}{l}\text { Net slip } \\
\text { (m) }\end{array}$ & $\begin{array}{c}\text { Throw } \\
\text { (m) }\end{array}$ & $\begin{array}{c}\text { Slip rate } \\
(\mathrm{mm} / \mathrm{y})\end{array}$ \\
\hline & Overall fault & 14 & $\approx 3.6 \mathrm{Ma}$ & $255-300$ & & $0.07-0.08$ \\
\hline Concud & $\begin{array}{l}\text { Los Baños } \\
\text { (SE sector) }\end{array}$ & 14 & $112-282 \mathrm{ka}$ & 39 & & $0.14-0.35$ \\
\hline & $\begin{array}{c}\text { El Hocino } \\
\text { (Central sector) }\end{array}$ & 14 & $82-66 \mathrm{ka}$ & 6.5 & & $0.08-0.10$ \\
\hline & llamocha & 17 & $\approx 3.6 \mathrm{Ma}$ & $215-250$ & & $0.06-0.07$ \\
\hline Sier & a Palomera & 16 & $\approx 3.6 \mathrm{Ma}$ & & $400-540$ & $0.11-0.15$ \\
\hline & & 11 & $\approx 11.1 \mathrm{Ma}$ & & 710 & 0.06 \\
\hline & & 11 & $\approx 3.6 \mathrm{Ma}$ & & 400 & 0.11 \\
\hline & & 10 & $\approx 3.6 \mathrm{Ma}$ & $215-235$ & & 0.06 \\
\hline & & 10 & $71-81 \mathrm{ka}$ & & 9 & $0.11-0.13$ \\
\hline Raml & a de la Viuda & $s$ & $3.6-5.0 \mathrm{Ma}$ & & $620-640$ & $0.12-0.18$ \\
\hline $\begin{array}{r}\text { Torre- } \\
\text { L }\end{array}$ & $\begin{array}{l}\text { ndomenech \& } \\
\text { Valltorta }\end{array}$ & $\mathrm{s}$ & $1.9-2.6 \mathrm{Ma}$ & & $40-70$ & $0.02-0.04$ \\
\hline & Xivert & $s$ & $3.6-5.0 \mathrm{Ma}$ & & $300-350$ & $0.06-0.10$ \\
\hline & rreblanca & $\mathrm{s}$ & $1.9-2.6 \mathrm{Ma}$ & & $90-100$ & $0.03-0.05$ \\
\hline
\end{tabular}

Table 4.- Synthesis of displacements and slip rates inferred for the studied active faults.

Tabla 4.- Síntesis de los desplazamientos y velocidades de deslizamiento inferidos para las fallas activas estudiadas 


\section{References}

Adrover, R. (1975): Principales yacimientos paleomastológicos de la provincia de Teruel y su posición estratigráfica relativa. In: M.T. Alberdi, E. Aguirre (eds.), Actas I Coloq. Intern. Bioestratigrafia Continental del Neógeno Superior-Cuaternario Inferior. Trabajos del Neógeno-Cuaternario 4, 31-48.

Alcalá, L., Alonso-Zarza, A.M., Álvarez, M.A., Azanza, B., Calvo, J.P., Cañaveras, J.C., van Dam, J.A., Garcés, M., Krijgsman, W., van der Meulen, A.J., Morales, J., Peláez, P., Pérez-González, A., Sánchez, S., Sancho, R., Sanz, E. (2000): El registro sedimentario y faunístico de las cuencas de Calatayud-Daroca y Teruel. Evolución paleoambiental y paleoclimática durante el Neógeno. Revista de la Sociedad Geológica de España 13, 323-343.

Alfaro, P., Delgado, J., Sanz de Galdeano, C., Galindo-Zaldívar, J., García-Tortosa, F.J., López-Garrido, A.C., López-Casado, C., Marín, C., Gil, A., Borque, M.J. (2008): The Baza Fault: a major active extensional fault in the Central Betic Cordillera (South Spain). International Journal of Earth Sciences. doi: 10.1007/s00531-0070213-z.

Anadón, P., Moissenet, E. (1996): Neogene basins in the Eastern iberian Range. In: P.F. Friend, C.J. Dabrio (eds.), Tertiary basins of Spain. Cambridge Univ. Press, Cambridge: 68-76.

Arlegui, L.E., Simón, J.L., Lisle, R.J., Orife, T. (2005): Late PliocenePleistocene stress field in the Teruel and Jiloca grabens (eastern Spain): contribution of a new method of stress inversion. Journal of Structural Geology 27, 693-705. doi:10.1016/j.jsg.2004.10.013.

Arlegui, L.E., Simón, J.L., Lisle, R.J., Orife, T. (2006): Analysis of non-striated faults in a recent extensional setting: the Plio-Pleistocene Concud fault (Jiloca graben, eastern Spain). Journal of Structural Geology 28, 1019-1027. doi:10.1016/j.jsg.2006.03.009.

Birot, P. (1959): Esquisse morphologique des Monts Celtibériques orientaux. Bull Comité Travaux Historiques et Scientifiques, Section Géographie I(72), 101-130.

Casas, A.M., Cortés, A.L. (2002): Cenozoic landscape development within the Central Iberian Chain, Spain. Geomorphology 44, 19-46. doi:10.1016/S0169-555X(01)00129-5.

Cowie, P.A., Roberts, G.P. (2001): Constraining slip rates and spacings for active normal faults. Journal of Structural Geology 23, 1901-1915. doi:10.1016/S0191-8141(01)00036-0.

García-Tortosa, F.J., Sanz de Galdeano, C., Sánchez-Gómez, M., Alfaro, P. (2008): Geomorphologic evidence of the active Baza Fault (Betic Cordillera, South Spain). Geomorphology 97, 374391. doi:10.1016/j.geomorph.2007.08.007.

Godoy, A., Ramírez, J.I., Olivé, A., Moissenet, E., Aznar, J.M., Aragonés, E., Aguilar, M.J., Ramírez del Pozo, J., Leal, M.C., JerezMir, L., Adrover, R., Goy, A., Comas, M.J., Alberdi, M.T., Giner, J., Gutiérrez-Elorza, M., Portero, J.M., Gabaldón, V. (1983a): Hoja geológica num. 567 (Teruel). Mapa Geológico de España E. 1:50.000. IGME, Madrid.

Godoy, A., Olivé, A., Moissenet, E. (1983b). Hoja geológica num. 542 (Alfambra). Mapa Geológico de España E. 1:50.000. IGME, Madrid.

González, A., Guimerà, J., Luzón, A. (1998): Edad Oligoceno superior-Mioceno inferiore para las superfícies de erosión conservadas en el flanco SW de la cubeta de Bordón. (Provincia de Teruel, España). Geogaceta 24, 155-158.

Guimerà, J., González, A. (1998): El relieve de la Cadena Ibérica como producto de la compresión alpina. Geogaceta 24, 163-166.

Gracia, F.J., Gutiérrez, F., Gutiérrez, M. (2003): The Jiloca karst polje-tectonic graben (Iberian Range, NE Spain). Geomorphology 52, 215-231. doi:10.1016/S0169-555X(02)00257-X.
Gracia, F.J., Gutiérrez, M., Leránoz, B. (1988): Las superficies de erosión neógenas en el sector central de la Cordillera Ibérica. Revista de la Sociedad Geológica de España 1, 135-142.

Gutiérrez, M., Gracia, F.J. (1997): Environmental interpretation and evolution of the Tertiary erosion surfaces in the Iberian Range (Spain). In: M. Widdowson (ed.), Palaeosurfaces; Recognition, Reconstruction and Palaeoenvironmental Interpretation. Geological Society Special Publication, London 120: 147-158. doi:10.1144/ GSL.SP.1997.120.01.10.

Gutiérrez, F., Gutiérrez, M., Gracia, F.J., McCalpin, J.P., Lucha, P., Guerrero, J. (2008): Plio-Quaternary extensional seismotectonics and drainage network development in the central sector of the Iberian Range (NE Spain). Geomorphology 102, 21-42. doi:10.1016/j. geomorph.2007.07.020.

Gutiérrez, F., Masana, E., González, A., Lucha, P., Guerrero, J., McCalpin, J. (2009): Late Quaternary paleoseismic evidence on the Munébrega half-graben fault (Iberian Range, Spain). International Journal of Earth Sciences 98, 1691-1703. doi:10.1007/s00531-0080319-y.

Gutiérrez, F., Lucha, P., Guerrero, J., Gutiérrez, M., Carbonel, D. (2011): Discussion on the article "Paleoseismological analysis of an intraplate extensional structure: the Concud fault (Iberian Chain, Eastern Spain)" by P. Lafuente, L.E., Arlegui, C.L. Liesa, and J.L. Simón. International Journal of Earth Sciences. doi: 10.1007/ s00531-011-0660-4.

Gutiérrez, M., Peña, J.L. (1976): Glacis y terrazas en el curso medio del río Alfambra (provincia de Teruel). Boletín Geológico y Minero 87, 561-570.

Hernández, A., Olivé, A., Moissenet, E., Pardo, G., Villena, J., Portero, J.M., Gutiérrez, M., Aguilar, M.J., Leal, M.C. (1983): Hoja geológica num. 491 (Calamocha). Mapa Geológico de España E. 1:50.000. IGME, Madrid.

Herraiz, M., De Vicente, G., Lindo-Ñaupari, R., Giner, J., Simón, J.L., González-Casado, J.M., Vadillo, O., Rodríguez-Pascua, M.A., Cicuéndez, J.I., Casas, A., Cabañas, L., Rincón, P., Cortés, A.L., Ramírez, M., Lucini, M. (2000): The recent (upper Miocene to Quaternary) and present tectonic stress distributions in the Iberian Peninsula. Tectonics 19, 762-786. doi:10.1029/2000TC900006.

Lafuente, P. (2011): Tectónica activa y paleosismicidad de la falla de Concud (Cordillera Ibérica central). PhD Thesis, Universidad de Zaragoza, Zaragoza: 338 p.

Lafuente, P., Simón, J.L., Rodríguez-Pascua, M.A., Arlegui, L.E., Liesa, C.L. (2007): Aproximación al comportamiento paleosísmico de la falla de Concud (Teruel, Cordillera Ibérica). Actas III Congreso Nacional de Ingeniería Sísmica. Asociación Española de Ingeniería Sísmica, Girona: 211-223.

Lafuente, P., Arlegui, L.E., Liesa, C.L., Simón, J.L. (2008a): Paleoseismological analysis at a railway trench across an intraplate extensional structure: the Concud fault. 33rd International Geological Congress 2008, Oslo (Noruega): STP-02.

Lafuente, P., Rodríguez-Pascua, M.A., Simón, J.L., Arlegui, L.E., Liesa, C.L. (2008b): Sismitas en depósitos pliocenos y pleistocenos de la fosa de Teruel. Revista de la Sociedad Geológica de España 21, 133-149.

Lafuente, P., Arlegui, L.E., Liesa, C.L., Simón, J.L. (2010a): Paleoseismological analysis of an intraplate extensional structure: the Concud fault (Iberian Chain, Spain). International Journal of Earth Sciences 100, 1713-1732. doi: 10.1007/s00531-010-0542-1.

Lafuente, P., Arlegui, L.E., Liesa, C.L., Simón, J.L. (2010b): Nuevo estudio paleosismológico en el sector central de la falla de Concud (Fosa del Jiloca, Teruel): resultados preliminares. In: J.M. Insua, F. Martín-González (ed.), Contribución de la Geología al Análisis de la Peligrosidad Sísmica. Primera reunión ibérica sobre fallas acti- 
vas y paleosismología. Sigüenza (Guadalajara): 67-70.

Lafuente, P., Arlegui, L.E., Liesa, C.L., Simón, J.L. (2011): Reply to the discussion by F. Gutiérrez, P. Lucha, J. Guerrero, M. Gutiérrez and D. Carbonel on the article "Paleoseismological analysis of an intraplate extensional structure: the Concud fault (Iberian Chain, Spain)". International Journal of Earth Sciences 100. doi: 10.1007/ s00531-011-0661-3.

Liesa, C.L. (2011): Fracturación extensional cretácica en la Sierra del Pobo (Cordillera Ibérica, España). Revista de la Sociedad Geológica de España 24: 23-40.

Lozano, M.V. (1988): Estudio geomorfológico de las Sierras de Gúdar (prov. de Teruel). PhD Thesis. Universidad de Zaragoza, Zaragoza: $765 \mathrm{p}$.

Masana, E., Villamarin, J.A, Santanach, P. (2001): Paleoseismic results from multiple trenching analysis along a silent fault: The El Camp fault (Tarragona, northeastern Iberian Peninsula). Acta Geológica Hispánica 36, 329-354.

Mohammadioun, B., Serva, L. (2001): Stress drop, slip type, earthquake magnitude, and seismic hazard. Bulletin of the Seismological Society of America 91, 694-707. doi:10.1785/0120000067.

Moissenet, E. (1980): Relief et déformations récentes: trois transversales dans les fossés internes des chaînes Ibériques orientales. Revue de Géographie des Pyrenées et Sud-Ouest 51, 315-344.

Moissenet, E. (1982): Le Villafranchien de la région de Teruel (Espagne). Stratigraphie-deformations-milieux. Colloque "Le Villafranchien méditerranéen», Lille: 229-253.

Moissenet, E. (1983): Aspectos de la neotectónica en la fosa de Teruel. In: J.A. Comba (coord.), Geología de España (Libro Jubilar J.M. Ríos). I.G.M.E. Madrid, 2: 427-446.

Moissenet, E. (1993): L'age et les déformations des terrases alluviales du Fossé de Teruel. In: El Cuaternario de España y Portugal, I.G.M.E.-A.E.Q.U.A. Madrid, 1: 267-279.

Opdyke, N., Mein, P., Lindsay, E., Pérez-González, A., Moissenet, E., Norton, V.L. (1997): Continental deposits, magnetostratigraphy and vertebrate paleontology, late Neogene of Eastern Spain. Palaeogeography, Palaeoclimatology, Palaeoecology 133, 129-148. doi:10.1016/S0031-0182(97)00080-1.

Pailhé, P. (1984): La Chaîne Ibérique Orientale. Étude géomorphologique. PhD Thesis. Universitè de Bordeaux (France): $682 \mathrm{p}$.

Pavlides, S., Caputo, R. (2004): Magnitude versus faults' surface parameters: quantitative relationships from the Aegean Region. Tectonophysics 380, 159-188. doi:10.1016/j.tecto.2003.09.019.

Peña, J.L. (1981): Las acumulaciones cuaternarias de la confluencia de los ríos Alfambra y Guadalaviar, en las cercanías de Teruel. Actas VII Coloquio de Geografia, Pamplona: 255-259.

Peña, J.L., Gutiérrez, M., Ibáñez, M.J., Lozano, M.V., Rodríguez, J., Sánchez, M., Simón, J.L., Soriano, M.A., Yetano, L.M. (1984): Geomorfología de la provincia de Teruel. Instituto de Estudios Turolenses, Teruel: $149 \mathrm{p}$.

Perea, H. (2006): Falles actives i perillositat sísmica al marge nordoccidental del solc de Valencia. PhD Thesis. Universitat de Barcelona, Barcelona (Spain): 317 p.

Pérez, A.J., Simón, J.L. (1993): Cambios en el trazado de la red fluvial producidos por la tectónica cuaternaria en el sistema de fosas del Maestrat. In: El Cuaternario de España y Portugal, I.G.M.E.A.E.Q.U.A. Madrid 2: 707-715.

Reicherter, K., Jabaloy, A., Galindo-Zaldívar, J., Becker-Heidmann, P., Sanz de Galdeano, C. (2010): Trenching results of the Ventas de Zafarraya fault (Southern Spain). In: J.M. Insua, F. Martín-González (ed.), Contribución de la Geología al Análisis de la Peligrosidad Sísmica. Primera reunión ibérica sobre fallas activas y paleosismología. Sigüenza (Guadalajara): p. 125.
Roberts, G.P., Michetti, A.M., Cowie, P., Nigel C. Morewood, N.C., Papanikolaou, I. (2002): Fault slip-rate variations during crustalscale strain localisation, central Italy. Geophysical Research Letters 29 (8), 1168. doi:10.1029/2001GL013529.

Roca, E., Guimerà, J. (1992): The Neogene structure of the eastern Iberian margin: structural constraints on the crustal evolution of the Valencia trough (western Mediterranean). Tectonophysics 203, 203 218. doi:10.1016/0040-1951(92)90224-T.

Rubio, J.C., Simón, J.L. (2007): Tectonic subsidence v. erosional lowering in a controversial intramontane depression: the Jiloca basin (Iberian Chain, Spain). Geological Magazine 144, 1-15. doi:10.1017/S0016756806002949.

Rubio, J.L., Simón, J.L., Soriano, M.A. (2007): Interacting tectonics, hydrogeology and karst processes in an intramontane basin: the Jiloca graben (NE Spain). Hydrogeology Journal 15, 1565-1576. doi:10.1007/s10040-007-0190-0.

Salvador, T., Simón, J.L. (1990): Un ejemplo de valles decapitados en las fosas cuaternarias del Maestrazgo (Castellón). Actas I Reunión Nacional de Geomorfología, Teruel: 61-70.

Sánchez Fabre, M. (1989): Geomorfología de la Depresión de Alfambra-Teruel-Landete y sus rebordes montañosos. $\mathrm{PhD}$ Thesis. Universidad de Zaragoza, Zaragoza: 926 p.

Sanz de Galdeano, C., Peláez, J.A., López-Casado, C. (2003): Seismic potential of the main active faults in the Granada Basin (Southern Spain). Pure and Applied Geophysics 160, 1537-1556. doi:10.1007/ s00024-003-2359-3.

Simón, J.L. (1982): Compresión y distensión alpinas en la Cadena Ibérica Oriental. PhD. Thesis, Universidad de Zaragoza. Publ. Instituto de Estudios Turolenses, Teruel (1984): 269 p.

Simón, J.L. (1983): Tectónica y neotectónica del sistema de fosas de Teruel. Teruel 69, 21-97.

Simón, J.L. (1989): Late Cenozoic stress field and fracturing in the Iberian Chain and Ebro Basin (Spain). Journal of Structural Geology 11, 285-294. doi:10.1016/0191-8141(89)90068-0.

Simón, J.L. (2007): La construcción y el modelado del relieve en la Cordillera Ibérica. Enseñanza de las Ciencias de la Tierra 15, 164174.

Simón, J.L., Lafuente, P., Arlegui, L.E., Liesa, C.L., Soriano, M.A. (2005): Caracterización paleosísmica preliminar de la falla de Concud (fosa del Jiloca, Teruel). Geogaceta 38, 63-66.

Simón, J.L., Pérez, A., Calvo, A. (1983): Morfogénesis y neotectónica en el sistema de fosas del Maestrat (provincia de Castellón). Estudios Geológicos 39, 167-177.

Simón, J.L., Rubio, J.C., Soriano, M.A. (2010): Sobre el origen y edad de la depresión del Jiloca (Teruel, Cordillera Ibérica centro-oriental). Geogaceta 48, 183-186.

Sinusía, C., Pueyo, E.L., Azanza, B., Pocoví, A. (2004): Datación magnetoestratigráfica del yacimiento paleontológico de La Puebla de Valverde (Teruel). Geo-Temas 6(4), 339-342.

Stirling, M., Rhoades, D., Berryman, K. (2002): Comparision of Earthquake Scaling Relations Derived from Data of the Instrumental and Preinstrumental Era. Bulletin of the Seismological Society of America 92, 812-830. doi:10.1785/0120000221.

Vegas, R., Fontboté, J.M., Banda, E. (1979): Widespread Neogene rifting superimposed on alpine regions of the Iberian Peninsula. Proceedings Symposium Evolution and Tectonics of the Western Mediterranean and Surrounding Areas, EGS, Viena. Instituto Geográfico Nacional, Madrid, Special Publication 201: 109-128.

Wells, D.L., Coppersmith, K.J. (1994): New Empirical Relationships among Magnitude, Rupture Length, Rupture Width, Rupture Area, and Surface Displacement. Bulletin of the Seismological Society of America 84, 974-1002. 